\title{
Identification and classification of innexin gene transcripts in the central nervous system of the terrestrial slug Limax valentianus
}

\section{Hisayo Sadamoto $^{18}$, Hironobu Takahashi ${ }^{2}$, Suguru Kobayashi ${ }^{1}$, Hirooki Kondoh ${ }^{1}$, Hiroshi Tokumaru ${ }^{1}$}

${ }^{1}$ Faculty of Pharmaceutical Sciences at Kagawa Campus, Tokushima Bunri University, Shido, Sanuki-City, Kagawa, 769-2193, Japan

${ }^{2}$ Faculty of Pharmaceutical Sciences, Tokushima Bunri University, Yamashiro-cho, Tokushima, 770-8514, Japan

${ }^{\S}$ Corresponding author

Email addresses:

HS: sadamotoh@kph.bunri-u.ac.jp

HT1: taka@ph.bunri-u.ac.jp

SK: kobayashis@kph.bunri-u.ac.jp

HK: s158102@stu.bunri-u.ac.jp

HT2: tokumaruh@kph.bunri-u.ac.jp 


\section{Abstract}

In invertebrates, innexin is involved in the formation of single-cell membrane channels and intercellular gap junction channels. Generally, there are multiple isoforms of innexin family proteins in various animal species, which enable the precise regulation of channel function. In molluscan species, the sequence information of innexins is still limited and the sequences have not been classified.

This study examined the innexin transcripts expressed in the central nervous system of the terrestrial slug Limax valentianus and identified 16 transcripts of 12 innexin isoforms, including the splicing variants. To examine the function of molluscan innexin isoforms, phylogenetic analysis was performed using the innexin sequences of molluscan species. Next, the phosphorylation, N-glycosylation, and S-nitrosylation sites in the isoforms were predicted to characterize the innexin isoforms. Further, 16 circular RNA sequences of nine innexin isoforms were identified in the central nervous system of Limax. The identification and classification of the gene transcripts of molluscan innexins provided novel insights for understanding the regulatory mechanism of innexins in the central nervous system. 


\section{Introduction}

Gap junction channels are formed by docking of single-cell membrane channels between adjacent cells, and that allow intercellular communication via the exchange of small molecules such as ions, nucleotides, small peptides and micro RNA (miRNA). Recent studies have indicated that the gap junction-related proteins are involved in the regulation of brain function. Neuronal gap junctions, which are known as electrical synapses, exhibit plasticity (1)(2). The single-cell membrane channels are involved in neuroplasticity through interaction with the chemical synapses (3)(2). The channel properties of gap junction-related proteins are regulated through protein modifications, such as N-glycosylation, S-nitrosylation, and phosphorylation (4)(5)(6)(7).

Three family proteins, innexin in invertebrate, connexin and pannexin in vertebrate, are known as the gap junction-related proteins. These three family proteins share structural features that are characterized by four transmembrane domains, two extracellular loops, and intracellular N- and C-terminal domains (8). The hexamers, heptamers, and octamers of these proteins form a single-cell membrane channel (9)(10). Additionally, the multiple isoforms of these proteins contribute to the specialized regulation of the channel property and the intercellular docking of the single-cell membrane channels. Previous studies have also reported the differential characteristics of the three family proteins $(11)(12)$. In vertebrates, connexin proteins form both single-cell membrane channels and intercellular gap junctions. However, pannexin proteins form only single-cell membrane channels in vivo as glycosylation at their extracellular domain inhibits the formation of intercellular gap junction channels. In invertebrates, innexin exhibits the functions of both connexin and pannexin. The 
classification and function of invertebrate innexin isoforms have not been completely understood.

In molluscan species, molecular biological analyses of innexins remain even untouched, even though various studies have examined the electrical synapses in the central nervous system (CNS) (13)(14)(15). For example, in the CNS of the terrestrial slug Limax, electrophysiological studies have demonstrated the electrical synapses exist in the procerebral lobe (16) and in the identified neurons of the buccal ganglion (17). Recent studies have also performed the genomic and transcriptome analyses of various molluscan species $(18)(19)(20)(21)(22)$. Whereas, there are limited studies on the molluscan innexin genes. In the pteropod mollusk Clione limacina, early studies identified two putative gap junction protein genes (23), and demonstrated that the electrical coupling was altered by the mRNA injection of one gap junction protein-coding gene (24). Recently, eight innexin gene transcripts were identified in the gastropod mollusk Lymnaea stagnalis (25). The sequence information of molluscan innexins is still limited and these identified innexin homologs have not been classified.

This study aimed to identify innexin gene transcripts, including circular RNAs (circRNAs), in the CNS of the terrestrial slug Limax valentianus. Additionally, comparative and phylogenetic analyses of the predicted amino acid sequences of molluscan species were performed to classify the innexin homologs. 


\section{Methods}

\section{Animals}

All experiments were performed using the terrestrial slugs L. valentianus at 3-4 months post-hatching. The animals were maintained under laboratory conditions at $19{ }^{\circ} \mathrm{C}$ with a 12-h light/dark cycle. To anesthetize the animals before dissection, magnesium chloride solution was injected. The isolated CNS was frozen in liquid nitrogen for RNA extraction.

\section{Protein sequence analyses of predicted innexin homologs}

Phylogenetic analysis was performed using the available molluscan innexin protein sequences in the Swissprot, Genbank, and Refseq databases with basic local alignment search tool (BLAST). Multiple sequence alignment of molluscan innexin homologs was performed using MUSCLE. The phylogenetic tree was constructed using the maximum likelihood method with MEGAX software (26).

The potential phosphorylation sites of protein kinase $\mathrm{C}(\mathrm{PKC})$, protein kinase $\mathrm{A}$ (PKA), protein kinase $\mathrm{G}(\mathrm{PKG})$, casein kinase 1 (CK1), casein kinase 2 (CK2), proto-oncogene tyrosine-protein kinase Src (SRC), P34cdc (cdc2), calmodulin-dependent protein kinase (CaMK), and mitogen-activated protein kinase (p38MAPK) were predicted using NetPhos 3.1 Server (27). Potential S-nitrosylation and N-glycosylation sites were predicted using GPS-SNO1.0 (28) and NetNGlyc 1.0 Server analysis (http://sno.biocuckoo.org/ and http://www.cbs.dtu.dk/services/NetNGlyc/), respectively. The consensus peptide 
sequence for N-glycosylation (Asn-X-Ser/Thr; $\mathrm{X}$ is not Pro) is conserved in both vertebrates and invertebrates(29)(30).

\section{Polymerase chain reaction (PCR)}

The sequence-specific primers for Limax innexin mRNAs were designed based on the innexin homolog sequences in the Limax CNS identified through transcriptome shotgun assembly (TSA) (under published). For amplifying circRNA, divergent primers were designed based on the verified complementary DNA (cDNA) sequences. The primer sequences are listed in Supplemental Table 1. RNA was extracted from the dissected CNS of three animals using the Nucleospin RNA XS kit and treated with DNAse I (Macherey \& Nagel, Düren, Germany). Total RNA (100 ng) was reverse-transcribed using M-MLV reverse transcriptase (Invitrogen, Carlsbad, CA) and random primers, following the manufacturer's instructions. The cDNA was subjected to PCR using ExTaq DNA polymerase (Takara Co., Otsu, Japan) or PrimeSTAR GXL DNA polymerase kit (Takara Co.). The amplicons were subcloned into the TOPO ${ }^{\mathrm{TM}}$ vector (Invitrogen) and subjected to nucleotide sequencing analysis. 


\section{Results}

\section{Identification of Limax innexin homologs}

To identify the gap junction protein gene transcripts, a local BLASTX search was performed using Aplysia innexin homologs for TSA of L. valentianus CNS. The cDNA sequences from the TSA data were cloned and subjected to nucleotide sequencing. In this study, 16 Limax innexin homologs (Limax innexins 1-11, including spliced isoforms, and partial coding domain sequence (CDS) of Limax innexin 12: accession number LC595664-LC595679) were identified.

The deduced protein sequences were used for the prediction of transmembrane domain using OCTOPUS software (31). All obtained Limax innexin homologs exhibited typical characteristics of innexin proteins (four transmembrane domains that are connected by the first and second extracellular loops and one intracellular loop) (Fig. 1). Amino acid alignment analysis further revealed that the identified Limax innexins have a P-X-X-X-W motif around the second transmembrane domain (e.g. Limax innexin 1 PNIFW $_{120-124}$; Fig. 1). The proline residue in this motif has been reported to function as a molecular hinge for voltage-dependent gating of connexin channels (32)(33). This motif is conserved in all the innexin/pannexin family proteins (34).

Another typical characteristic of innexin proteins is the conserved cysteine (Cys) residues in the extracellular loops (34). In invertebrate innexin, two pairs of Cys form essential intramolecular disulfide bonds between the first and second extracellular loops (35). The Limax innexin homologs have two Cys residues in the first and second extracellular loops (e.g. Limax innexin 1, $\mathrm{Cys}_{56}$ and $\mathrm{Cys}_{74}$ in the first extracellular loop; $\mathrm{Cys}_{262}$ and $\mathrm{Cys}_{279}$ in the second extracellular loop) (Fig. 1). 
Interestingly, Limax innexins 1-9, except Limax innexin 4, have an additional Cys between the two Cys residues in the first extracellular loop (e.g. Limax innexin 1, $\mathrm{Cys}_{58}$ ) (Fig. 1). The additional Cys residue was also detected in the same region of other innexin/pannexin family protein sequences of some species listed in the public databases. In invertebrates, the additional Cys residue was detected in six of the 12 leech innexins (Hirudo medicinalis innexins 1, 3, 6, 9, 11, and 12). However, the additional Cys residue was not detected in the innexin sequences of insects and nematodes. In vertebrates, the additional Cys residue was detected in pannexin 3 of the clade Cetartiodactyla but not in pannexin 1 and 2, or connexin sequences (data not shown). These results indicate that the additional Cys residue is not a characteristic feature of molluscan innexins. However, the function of this additional Cys residue has not been reported in the innexin and pannexin proteins of any animal species.

The sequence alignment analysis also revealed differences in the identified Limax innexins (Fig. 1). The lengths of the extracellular loops were well conserved among Limax innexins 1-10 (the first extracellular loops, 53-55 amino acid residues; the second extracellular loop, 66-68 amino acid residues). However, only the length of the first extracellular loop in Limax innexin 11 was longer than that in other homologs (the first extracellular loop, 69 amino acids; the second extracellular loop, 63 amino acids). Furthermore, Limax innexins 1-10 had similar spacing between the two Cys residues in the extracellular loops. Meanwhile, the spacing between the two Cys residue in the second extracellular loop of Limax innexin 11 was short (Limax innexins 1-10, 16 amino acids; Limax innexins 11, 12 amino acids). Previous studies on vertebrate connexins have reported that the amino acid sequences between the Cys residues in the 
extracellular loop are critical for the formation of functional intercellular channels (9)(36)(37). Thus, we here suggest that Limax innexin isoforms can be broadly classified into two groups (Limax innexins 1-10 and Limax innexin 11). Interestingly, the present findings also appeared similar to the previous reports that vertebrate connexin and pannexin differ in the lengths of the extracellular loops (38)

\section{Molecular phylogenetic analysis of molluscan innexin homologs}

Next, molecular phylogenetic analysis was performed to classify and examine the characteristics of identified Limax innexins. The innexin genes were reported to exhibit phylum-specific diversification in each phyla Arthropoda, Nematoda, and Mollusca (39). Hence, phylogenetic analysis was performed on the available molluscan innexin sequences in the Swissprot, Genbank, and Refseq protein databases. Additionally, the hypothetical protein sequences from the genomic data of Elysia chlorotica (BioProject PRJNA484060; sequence and assembled genome) and previously reported molluscan innexin sequences were used for the phylogenetic analysis (24)(25). In the pond snail Lymnaea stagnalis, in addition to the reported eight innexin transcripts (LstInx1 to LstInx8) (25), two homolog sequences were identified in another transcriptome data of the CNS (Lymnaea FX186689 and Lymnaea FX187001) (19). One variant of each gene was used if splicing variants were detected. The accession numbers for the same amino acid sequence are summarized in Figure 2 (e.g. Crassostrea gigas unc-9 isoformx1: EKC18227.1, XP011418374.1). The numbers of sequences in different animal species were as follows: $n=20$ for Aplysia californica (Gastropoda); $n=10$ for Lymnaea 
stagnalis (Gastropoda); $n=2$ for Clione limacina (Gastropoda); $n=14$ for Biomphalaria glabrata (Gastropoda); $n=11$ for Pomacea canaliculata (Gastropoda); $n=12$ for Lottia gigantea (Gastropoda); $n=14$ for Elysia chlorotica (Gastropoda); $n=20$ for Mizuhopecten yessoensis (Bivalvia); $n=14$ for Crassostrea gigas (Bivalvia); $n=9$ for Octopus bimaculoides (Cephalopoda); $\mathrm{n}=1$ for Sepioteuthis lessoniana (Cephalopoda).

Molecular phylogenetic analysis revealed that the identified Limax innexin gene transcripts expressed in the CNS can be classified into seven ortholog groups (Fig. 2;

Group 1, Limax innexins 1 and 2; Group 2, Limax innexins 3 and 4; Group 3, Limax innexin 5; Group 4, Limax innexins 6 and 7; Group 5, Limax innexins 8 and 9; Group 6, Limax innexin 10; Group 7, Limax innexins 11 and 12). The number of innexin homolog genes varied among species (e.g. $n=20$ for Aplysia californica; $n=14$ for Elysia chlorotica). Consistent with this finding, a previous study on vertebrate connexins demonstrated that the number of connexin genes in zebrafish $(n=37)$ was approximately two times higher than that in humans $(n=20)$ and mice $(n=19)(40)$. The authors suggested that gene duplication events occur continuously in each phylum, which contribute to the species-specific regulation by gap junction-related proteins.

\section{Prediction of post-translational modification sites: N-glycosylation, S-nitrosylation, and phosphorylation}

To classify the molluscan innexin homologs, potential protein modification sites in the deduced amino acid sequences of the seven groups were examined. The predicted 
modification sites in the innexin sequences of each group are shown in Figures 3-9. The conserved modification sites between orthologs are summarized in Figure 10.

Potential N-glycosylation sites were detected only in the innexin homologs of Groups 2 and 7. In Group 2, one potential N-glycosylation site was identified at the first extracellular loop in two of the six orthologs (Limax innexin 3, $\mathrm{N}_{227} \mathrm{FT}$; Biomphalaria XP013085202.1 partial CDS sequence, $\mathrm{N}_{110}$ YS). In Group 7, two N-glycosylation sites were identified in the first extracellular loop in all orthologs of Group 7 (Limax innexin 11 splice variants, Limax innexin $11 \mathrm{x} 1, \mathrm{~N}_{85} \mathrm{MT}$ and $\mathrm{N}_{102} \mathrm{ET}$; Limax innexin $11 \mathrm{x} 2, \mathrm{~N}_{85} \mathrm{LS}$ and $\mathrm{N}_{102}$ ET; Lymnaea FX187001, $\mathrm{N}_{85} \mathrm{LS}$ and $\mathrm{N}_{102}$ ET; Elysia EGW08_022284 partial sequence, $\mathrm{N}_{102} \mathrm{AT}$; Biomphalaria innexin-19-likex1 N-terminal partial sequence, $\mathrm{N}_{118} \mathrm{LS}$ and $\mathrm{N}_{134} \mathrm{TT}$; Aplysia innexin unc-9-likex2, $\mathrm{N}_{85} \mathrm{LS}$ and $\mathrm{N}_{101} \mathrm{LT}$ ), except Limax innexin 12 for which the sequence information of the whole coding region was not available.

This indicated that $\mathrm{N}$-glycosylation modification occurs in the molluscan innexins of certain ortholog groups. The N-glycosylation sites of molluscan innexins are conserved in the first extracellular loop of all orthologs in Group 7. Consistent with this finding, vertebrate pannexin proteins have $\mathrm{N}$-glycosylation sites at the extracellular loops, whereas almost all connexins do not have the N-glycosylation sites.

$\mathrm{N}$-glycosylation of pannexins regulates subcellular localization and intermixing of different pannexins for channel formation (41)(42). Additionally, $\mathrm{N}$-glycosylation of pannexin inhibits the intercellular docking of neighboring pannexin channels and the formation of gap junctions (43)(42). Interestingly, molluscan innexin sequences of Group 7 exhibited the following two pannexin-like characteristics: N-glycosylation at 
the extracellular loops and longer extracellular loops than the innexin homologs in other groups.

Next, the S-nitrosylation sites were examined in the molluscan innexin homologs of the seven groups. The S-nitrosylation sites were identified in some homologs. The conserved S-nitrosylation sites were identified only in the intracellular loops of the orthologs of Groups 4 and 5 (Figs. 6, 7 and 10). S-nitrosylation, which is the covalent addition of nitric oxide (NO) to the Cys residue, is reported to be involved in the regulation of channel properties, such as channel permeability and voltage-sensitive gating of vertebrate connexins and pannexins (44)(45)(46). Various studies have examined the role of NO in the CNS of molluscan species (47)(48)(49)(50)(17). The findings of this study indicate that NO may regulate some molluscan innexins that belong to phylogenetically related groups.

Further, the phosphorylation sites of several kinases, including PKC, PKA, PKG, CK1, CK2, SRC, cdc2, CaMK, and p38MAPK, were examined (Figs. 3-9). These kinases phosphorylate vertebrate connexin/pannexin and regulate protein functions, such as oligomerization, channel properties, intracellular trafficking, gap junction assembly, and stability (5)(51)(6)(52). The characteristics of the sequences in each ortholog group are shown in Figures 3-9 and 10. The phosphorylation sites in PKG, CaMK, and p38MAPK were not conserved in the ortholog groups. Among the seven ortholog groups, the number of phosphorylation sites was high in Group 4. The conserved phosphorylation sites of cdc2 were detected only in this group (Figs. 6 and 10). Although Groups 4 and 5 were phylogenetically related (Fig. 2), the innexin homologs of Group 5 exhibited a decreased number of phosphorylation sites (Figs. 7 
and 10). This suggested that the predicted phosphorylation sites are conserved among the orthologs in each group and that each group exhibits a distinctive phosphorylation pattern.

Among the seven groups, the orthologs of Group 2 exhibited low sequence homology. Additionally, the protein modification sites in the orthologs of Group 2 were more variable than those in the orthologs of other groups (Figs. 4 and 10). Interestingly, Limax innexins 3 and 4 exhibited the highest degree of sequence homology. However, the protein modification sites were different between Limax innexins 3 and 4 (Figs. 2 and 10). At the extracellular loop, Limax innexin 3 had an N-glycosylation site, while Limax innexin 4 had two S-nitrosylation sites. The number of phosphorylation sites in the intracellular carboxyl-terminal domain of Limax innexin 3 was higher than that in the intracellular carboxyl-terminal domain of Limax innexin $4\left(\mathrm{~T}_{385}, \mathrm{~T}_{391}\right.$, and $\mathrm{S}_{398}$ for PKC; $\mathrm{T}_{369}, \mathrm{~S}_{405}$, and $\mathrm{S}_{416}$ for $\mathrm{CK} 2$; and $\mathrm{S}_{377}$ and $\mathrm{S}_{398}$ for cdc2). The difference between molluscan innexin genes in Group 2 could arise from continuous duplication events, which may result in new functions for the innexin proteins in Group 2.

\section{CircRNA identification of Limax innexin genes}

Next, RT-PCR experiments were performed to examine the expression of Limax innexin transcripts in the CNS. Interestingly, multiple amplicons were obtained for some innexin homologs. Sequencing analysis revealed that these amplicons were circRNAs. CircRNA is a class of non-coding RNAs that are generated through alternative back-splicing, which connects the terminal 5' and 3' ends of linear 
pre-mRNA (53). Previous studies have demonstrated the presence of circRNAs in different animal species, such as mammals, insects, and nematodes (54)(55).

Interestingly, circRNA is abundant in the brain tissue and the circRNA-producing genes encode proteins related to synapse-related functions (54)(56). However, the function of circRNA has not been fully elucidated.

Previous studies indicate that circRNAs mainly comprise coding exons (55). To identify the circRNAs of the innexin genes, divergent primers were designed for the coding region of Limax innexin sequences. This study identified 16 circRNA sequences for nine Limax innexin genes (Table 2). CircRNA formation is observed among Limax innexins in the CNS. Some circRNAs encode the whole coding region (circINX2a, circINX3, and circINX7b). The result demonstrated that circRNAs are constitutively formed from the innexin genes in the CNS of Limax.

The functions of circRNAs generated from the connexin, pannexin, and innexin genes have not been elucidated. Thus, the circRNAs of vertebrate connexin and pannexin genes were examined using a database that contains $>32,000$ human circRNAs (57). CircRNA data were retrieved for four connexin genes (GJA1, connexin 43; GJB3, connexin 31; GJB5, connexin 31.1; GJC1, connexin 45) and one pannexin gene (PNX1, pannexin 1). Of these, circRNAs of connexin 45 (hsa_circ_0106948, hsa_circ_0106949, hsa_circ_0106950, hsa_circ_0106951, hsa_circ_0106952) and pannexin 1 (hsa_circ_0096811, hsa_circ_0096812, hsa_circ_0096813, and hsa_circ_0096814) were listed as the transcripts in the brain tissue. These data suggest that circRNA formation from innexin genes is not a characteristic event in mollusks or 
invertebrates and that circRNAs of some homolog genes (not all genes) are involved in the regulatory mechanism of a single-membrane channel and gap junction. 


\section{Discussion}

In this study, the innexin homologs expressed in the CNS of L. valentianus were identified and characterized. Phylogenetic analysis revealed that innexin genes in molluscan species and the ortholog groups exhibited diversity. The prediction of post-translational modifications, including phosphorylation, S-nitrosylation, and $\mathrm{N}$-glycosylation, revealed the characteristics of each group. Additionally, this study demonstrated the abundant expression of circRNA of innexin homologs in the CNS.

In invertebrate species, innexin is the only protein family and the multiple isoforms have not been classified. Based on the phylogenetic analysis, this study classified Limax innexin homologs in the CNS into seven groups of molluscan innexin orthologs. Interestingly, one ortholog group exhibited vertebrate pannexin-like characteristics with different lengths of the extracellular loops and glycosylation sites. Previous studies have demonstrated that the intercellular docking of two single-cell membrane channels is regulated by the interaction between the extracellular loops of gap junction-related proteins. Pannexin proteins mainly form single-cell membrane channels in vivo, and glycosylation of pannexin at the extracellular loop may inhibit the formation of intercellular channels (43) (12). So far, only one study has examined the glycosylation of innexin homologs in the yellow fever mosquito Aedes aegypti (58).

The study reported that two of the six Aedes innexins (AeInx3 and AeInx7) have putative glycosylation sites and that AeInx3 exhibited multiple bands in the western blot. The authors suggested that AeInx3 may be an important component of gap junctions. However, the study did not discuss the effect of glycosylation on intercellular channel formation. Regard to the previous studies of pannexin, the glycosylation status of 
AeInx3 protein could regulate the formation of single-membrane channels or intercellular gap junction channels. In this study, in addition to innexin orthologs in Group 7, Limax innexin 3 in Group 2 had an N-glycosylation site, which is not conserved among the orthologs, at the extracellular loop. Thus, Limax innexin 3 could form both gap junction channels and single-cell membrane channels, and the $\mathrm{N}$-glycosylation status of this protein could regulate the intercellular docking of the channels.

In addition to the $\mathrm{N}$-glycosylation sites, this study predicted the phosphorylation and S-nitrosylation sites and characterized molluscan innexins of the seven groups. Each group exhibited a distinctive protein modification pattern. Additionally, the protein modification sites were well conserved among the homologs of the same group (Table 1). This indicated that the regulatory mechanism of the channels is well conserved among orthologs. These results also indicate that similar to that in vertebrate connexins (40), the duplication divergence of innexin genes could generate multiple innexin isoforms in molluscan species.

Further, this study examined the formation of circRNAs from innexin genes. This study also detected connexin and pannexin circRNAs in the human circRNA database (59). However, there is no study that experimentally examined the existence of circRNA for gap junction-related proteins. So far, only one review has proposed that mammalian connexin 43-derived circRNA functions as a miRNA sponge during breast cancer initiation stages (60). However, this has not been experimentally demonstrated. And the function of circRNAs is currently under investigation. Some studies have reported that circRNAs function as miRNA sponges (55)(61). Recent studies have reported that 
several circRNAs are associated with polysomes and that circRNAs are translated (62)(63). In this study, 12 of the 16 Limax innexin circRNAs encoded an open reading frame. These circRNAs can act as a template for $\mathrm{N}$-terminal truncated innexin proteins. Interestingly, several studies have reported the unexpected functions of N-terminal truncated connexin that are generated from internal translation initiation (64)(65)(66). The short connexin 43 isoform is involved in trafficking the full-length connexin 43 to the gap junction site. Additionally, the short connexin 43 isoform directly regulates $\mathrm{N}$-cadherin transcription, which results in neural crest cell migration at an early developmental stage in the amphibian and mammalian cells. The translation of innexin circRNA may result in the generation of truncated innexin proteins, which may have uncharacterized roles, such as protein trafficking and regulation of gene expression. To examine this hypothesis, future studies must examine the expression and function of innexin proteins.

\section{Conclusion}

In this study, multiple innexin transcripts were identified in L. valentianus and the molluscan innexin sequences were phylogenetically classified. Additionally, circRNA formation was demonstrated in multiple innexin genes in the CNS, which provided novel insights for understanding the regulatory mechanism of gap-junction-related proteins. The findings of this study will facilitate further studies on the function of molluscan innexin proteins and contribute to future studies on the regulatory mechanisms of gap junction-related proteins. 


\section{Acknowledgments}

The authors would like to thank Tokushima Bunri University for financial support. The authors also thank Miyu Nakagawa, Satsuki Maejima, and Ko Sudo for helping with the molecular biology experiments. 


\section{References}

1. Welzel G, Schuster S. Long-term potentiation in an innexin-based electrical synapse. Sci Rep [Internet]. 2018;8(1):12579. Available from:

https://doi.org/10.1038/s41598-018-30966-w

2. Bhattacharya A, Aghayeva U, Berghoff EG, Hobert O. Plasticity of the Electrical Connectome of C. elegans. Cell. 2019;176(5):1174-1189.e16.

3. Zoidl G, Petrasch-Parwez E, Ray A, Meier C, Bunse S, Habbes HW, et al. Localization of the pannexin 1 protein at postsynaptic sites in the cerebral cortex and hippocampus. Neuroscience. 2007;146(1):9-16.

4. D'hondt C, Iyyathurai J, Vinken M, Rogiers V, Leybaert L, Himpens B, et al. Regulation of connexin- and pannexin-based channels by post-translational modifications. Biol Cell. 2013;105(9):373-98.

5. Pogoda K, Kameritsch P, Retamal MA, Vega JL. Regulation of gap junction channels and hemichannels by phosphorylation and redox changes $\square$ : a revision. BMC Cell Biol [Internet]. 2016;17(Suppl 1). Available from:

http://dx.doi.org/10.1186/s12860-016-0099-3

6. Boyce AKJ, Epp AL, Nagarajan A, Swayne LA. Transcriptional and post-translational regulation of pannexins. Biochim Biophys Acta - Biomembr [Internet]. 2018;1860(1):72-82. Available from:

https://doi.org/10.1016/j.bbamem.2017.03.004

7. Beyer EC, Berthoud VM. Gap junction gene and protein families: Connexins, innexins, and pannexins. Biochim Biophys Acta - Biomembr [Internet]. 
2018;1860(1):5-8. Available from: https://doi.org/10.1016/j.bbamem.2017.05.016

8. Barbe MT, Monyer H, Bruzzone R. Cell-cell communication beyond connexins: The pannexin channels. Vol. 21, Physiology. 2006. p. 103-14.

9. Maeda S, Nakagawa S, Suga M, Yamashita E, Oshima A, Fujiyoshi Y, et al. Structure of the connexin 26 gap junction channel at $3.5 \AA$ resolution. Nature [Internet]. 2009;458(7238):597-602. Available from: http://dx.doi.org/10.1038/nature07869

10. Oshima A, Tani K, Fujiyoshi Y. Atomic structure of the innexin-6 gap junction channel determined by cryo-EM. Nat Commun. 2016;7.

11. Penuela S, Gehi R, Laird DW. The biochemistry and function of pannexin channels. Biochim Biophys Acta - Biomembr [Internet]. 2013;1828(1):15-22. Available from: http://dx.doi.org/10.1016/j.bbamem.2012.01.017

12. Sosinsky GE, Boassa D, Dermietzel R, Duffy HS, Laird DW, MacVicar BA, et al. Pannexin channels are not gap junction hemichannels. Channels. 2011;5(3):193-7.

13. Rothwell CM, De Hoog E, Spencer GE. The role of retinoic acid in the formation and modulation of invertebrate central synapses. J Neurophysiol. 2017;117(2):692-704.

14. Katz PS, Quinlan PD. The importance of identified neurons in gastropod molluscs to neuroscience. Curr Opin Neurobiol [Internet]. 2019;56:1-7. Available from: http://www.sciencedirect.com/science/article/pii/S0959438818301600 
15. Dyakonova VE, Hernadi L, Ito E, Dyakonova TL, Chistopolsky IA, Zakharov IS, et al. The activity of isolated neurons and the modulatory state of an isolated nervous system represent a recent behavioural state. J Exp Biol.

2015;218(8):1151-8.

16. Copeland J, Gelperin A. Feeding and a serotonergic interneuron activate an identified autoactive salivary neuron in Limax maximus. Comp Biochem Physiol Part A Physiol [Internet]. 1983;76(1):21-30. Available from:

http://www.sciencedirect.com/science/article/pii/0300962983902876

17. Ermentrout B, Wang JW, Flores J, Gelperin A. Model for transition from waves to synchrony in the olfactory lobe of Limax. J Comput Neurosci.

$2004 ; 17(3): 365-83$.

18. Moroz LL, Edwards JR, Puthanveettil S V., Kohn AB, Ha T, Heyland A, et al. Neuronal Transcriptome of Aplysia: Neuronal Compartments and Circuitry. Cell. 2006;127(7):1453-67.

19. Sadamoto H, Takahashi H, Okada T, Kenmoku H, Toyota M, Asakawa Y. De novo sequencing and transcriptome analysis of the central nervous system of Mollusc Lymnaea stagnalis by deep RNA sequencing. PLoS One. 2012;7(8).

20. Albertin CB, Simakov O, Mitros T, Wang ZY, Pungor JR, Edsinger-Gonzales E, et al. The octopus genome and the evolution of cephalopod neural and morphological novelties. Nature. 2015;524(7564):220-4.

21. Liu C, Zhang Y, Ren Y, Wang H, Li S, Jiang F, et al. The genome of the golden apple snail Pomacea canaliculata provides insight into stress tolerance and invasive adaptation. Gigascience. 2018 Sep;7(9). 
22. Cai H, Li Q, Fang X, Li J, Curtis NE, Altenburger A, et al. Data descriptor: A draft genome assembly of the solar-powered sea slug elysia chlorotica. Sci Data. 2019;6:1-13.

23. Panchina Y, Kelmanson I, Matz M, Lukyanov K, Usman N, Lukyanov S. A ubiquitous family of putative gap junction molecules [2]. Curr Biol. 2000;10(13):473-4.

24. Kelmanson I V., Shagin DA, Usman N, Matz M V., Lukyanov SA, Panchin Y V. Altering electrical connections in the nervous system of the pteropod mollusc Clione limacina by neuronal injections of gap junction mRNA. Eur J Neurosci. $2002 ; 16(12): 2475-6$.

25. Mersman BA, Jolly SN, Lin Z, Xu F. Gap Junction Coding Innexin in Lymnaea stagnalis: Sequence Analysis and Characterization in Tissues and the Central Nervous System. Front Synaptic Neurosci. 2020;12:1.

26. Kumar S, Stecher G, Li M, Knyaz C, Tamura K. MEGA X: Molecular evolutionary genetics analysis across computing platforms. Mol Biol Evol. 2018;35(6):1547-9.

27. Blom N, Sicheritz-Pontén T, Gupta R, Gammeltoft S, Brunak S. Prediction of post-translational glycosylation and phosphorylation of proteins from the amino acid sequence. Proteomics. 2004;4(6):1633-49.

28. Xue Y, Liu Z, Gao X, Jin C, Wen L, Yao X, et al. GPS-SNO: Computational prediction of protein s-nitrosylation sites with a modified GPS algorithm. PLoS One. 2010;5(6):1-7. 
29. Lowenthal MS, Davis KS, Formolo T, Kilpatrick LE, Phinney KW. Identification of Novel N-Glycosylation Sites at Noncanonical Protein Consensus Motifs. J Proteome Res. 2016;15(7):2087-101.

30. Kaji H, Kamiie JI, Kawakami H, Kido K, Yamauchi Y, Shinkawa T, et al. Proteomics reveals n-linked glycoprotein diversity in Caenorhabditis elegans and suggests an atypical translocation mechanism for integral membrane proteins. Mol Cell Proteomics. 2007;6(12):2100-9.

31. Viklund H, Elofsson A. OCTOPUS: improving topology prediction by two-track ANN-based preference scores and an extended topological grammar.

Bioinformatics [Internet]. 2008 May 12;24(15):1662-8. Available from: https://doi.org/10.1093/bioinformatics/btn221

32. Suchyna TM, Xu LX, Gao F, Fourtner CR, Nicholson BJ. Identification of a proline residue as a transduction element involved in voltage gating of gap junctions. Nature. 1993 Oct;365(6449):847-9.

33. Ri Y, Ballesteros JA, Abrams CK, Oh S, Verselis VK, Weinstein H, et al. The role of a conserved proline residue in mediating conformational changes associated with voltage gating of Cx32 gap junctions. Biophys J [Internet]. 1999;76(6):2887-98. Available from: http://dx.doi.org/10.1016/S0006-3495(99)77444-8

34. Phelan P. Innexins: members of an evolutionarily conserved family of gap-junction proteins. Biochim Biophys Acta - Biomembr [Internet]. 2005 Jun 10 [cited 2020 Jan 24];1711(2):225-45. Available from: https://www.sciencedirect.com/science/article/pii/S0005273604002640\#bib51 
35. Oshima A. Structure of an innexin gap junction channel and cryo-EM sample preparation. Reprod Syst Sex Disord. 2017 Dec;66(6):371-9.

36. Gong XQ, Nakagawa S, Tsukihara T, Bai D. A mechanism of gap junction docking revealed by functional rescue of a human-disease-linked connexin mutant. J Cell Sci. 2013;126(14):3113-20.

37. Bai D, Yue B, Aoyama H. Crucial motifs and residues in the extracellular loops influence the formation and specificity of connexin docking. Biochim Biophys Acta - Biomembr. 2018;1860(1):9-21.

38. Panchin Y V. Evolution of gap junction proteins - The pannexin alternative. J Exp Biol. 2005;208(8):1415-9.

39. Turnbull MW, Hasegawa DK, Turnbull MW. Recent Findings in Evolution and Function of Insect Innexins . Author's personal copy Recent findings in evolution and function of insect innexins. 2014;(March).

40. Eastman SD, Chen THP, Falk MM, Mendelson TC, Iovine MK. Phylogenetic analysis of three complete gap junction gene families reveals lineage-specific duplications and highly supported gene classes. Genomics. 2006;87(2):265-74.

41. Sanchez-pupo RE. N-Glycosylation Regulates Pannexin 2 Localization but Is Not Required for Interacting with Pannexin 1. 2018;1-18.

42. Penuela S, Bhalla R, Nag K, Laird DW. Glycosylation Regulates Pannexin Intermixing and Cellular Localization. Mol Biol Cell. 2009;20:4313-23.

43. Boassa D, Qiu F, Dahl G, Sosinsky G. Trafficking dynamics of glycosylated pannexin1 proteins. Cell Commun Adhes. 2008;15(1-2):119-32. 
44. Lohman AW, Weaver JL, Billaud M, Sandilos JK, Griffiths R, Straub AC, et al. S-nitrosylation inhibits pannexin 1 channel function. J Biol Chem. 2012;287(47):39602-12.

45. Straub AC, Billaud M, Johnstone SR, Best AK, Yemen S, Dwyer ST, et al. Compartmentalized connexin 43 s-nitrosylation/denitrosylation regulates heterocellular communication in the vessel wall. Arterioscler Thromb Vasc Biol. 2011 Feb;31(2):399-407.

46. Retamal MA, Yin SY, Altenberg GA, Reuss L. Modulation of Cx46 hemichannels by nitric oxide. Am J Physiol - Cell Physiol. 2009;296(6).

47. Yabumoto T, Takanashi F, Kirino Y, Watanabe S. Nitric oxide is involved in appetitive but not aversive olfactory learning in the land mollusk Limax valentianus. Learn Mem. 2008;15(4):229-32.

48. Kobayashi S, Sadamoto H, Ogawa H, Kitamura Y, Oka K, Tanishita K, et al. Nitric oxide generation around buccal ganglia accompanying feeding behavior in the pond snail, Lymnaea stagnalis. Neurosci Res. 2000;38(1).

49. Sadamoto H, Hatakeyama D, Kojima S, Fujito Y, Ito E. Histochemical study on the relation between NO-generative neurons and central circuitry for feeding in the pond snail, Lymnaea stagnalis. Neurosci Res. 1998;32(1).

50. Fujie S, Aonuma H, Ito I, Gelperin A, Ito E. The Nitric Oxide/Cyclic GMP Pathway in the Olfactory Processing System of the Terrestrial Slug Limax marginatus. Zoolog Sci [Internet]. 2002 Jan 1;19(1):15-26. Available from: https://doi.org/10.2108/zsj.19.15 
51. Laird DW. Connexin phosphorylation as a regulatory event linked to gap junction internalization and degradation. Biochim Biophys Acta - Biomembr. 2005;1711(2 SPEC. ISS.):172-82.

52. Kanemitsu MY, Jiang W, Eckhart W. Cdc2-mediated phosphorylation of the gap junction protein, connexin43, during mitosis. Cell Growth Differ. 1998;9(1):13-21.

53. Ragan C, Goodall GJ, Shirokikh NE, Preiss T. Insights into the biogenesis and potential functions of exonic circular RNA. Sci Rep [Internet]. 2019;9(1):1-18. Available from: http://dx.doi.org/10.1038/s41598-018-37037-0

54. Westholm JO, Miura P, Olson S, Shenker S, Joseph B, Sanfilippo P, et al. Genome-wide Analysis of Drosophila Circular RNAs Reveals Their Structural and Sequence Properties and Age-Dependent Neural Accumulation. Cell Rep [Internet]. 2014;9(5):1966-80. Available from: http://dx.doi.org/10.1016/j.celrep.2014.10.062

55. Memczak S, Jens M, Elefsinioti A, Torti F, Krueger J, Rybak A, et al. Circular RNAs are a large class of animal RNAs with regulatory potency. Nature. 2013 Mar;495(7441):333-8.

56. You X, Vlatkovic I, Babic A, Will T, Epstein I, Tushev G, et al. Neural circular RNAs are derived from synaptic genes and regulated by development and plasticity. Nat Neurosci. 2015;18(4):603-10.

57. Dudekula DB, Panda AC, Grammatikakis I, De S, Abdelmohsen K, Gorospe M. Circinteractome: A web tool for exploring circular RNAs and their interacting 
proteins and microRNAs. RNA Biol [Internet]. 2016;13(1):34-42. Available from: http://dx.doi.org/10.1080/15476286.2015.1128065

58. Calkins TL, Woods-Acevedo MA, Hildebrandt O, Piermarini PM. The molecular and immunochemical expression of innexins in the yellow fever mosquito, Aedes aegypti: Insights into putative life stage- and tissue-specific functions of gap junctions. Comp Biochem Physiol Part - B Biochem Mol Biol. 2015 May;183:11-21.

59. Dudekula DB, Panda AC, Grammatikakis I, De S, Abdelmohsen K, Gorospe M. Circinteractome: A web tool for exploring circular RNAs and their interacting proteins and microRNAs. RNA Biol. 2016;13(1):34-42.

60. Naser Al Deen N, AbouHaidar M, Talhouk R. Connexin43 as a Tumor Suppressor: Proposed Connexin43 mRNA-circularRNAs-microRNAs Axis Towards Prevention and Early Detection in Breast Cancer. Front Med. 2019;6(August):1-8.

61. Hansen TB, Jensen TI, Clausen BH, Bramsen JB, Finsen B, Damgaard CK, et al. Natural RNA circles function as efficient microRNA sponges. Nature [Internet]. 2013;495(7441):384-8. Available from: http://dx.doi.org/10.1038/nature11993

62. Yang Y, Fan X, Mao M, Song X, Wu P, Zhang Y, et al. Extensive translation of circular RNAs driven by N 6 -methyladenosine. Cell Res. 2017;27(5):626-41.

63. Wang Y, Wang Z. Efficient backsplicing produces translatable circular mRNAs. Rna. 2015;21(2):172-9. 
64. Smyth JW, Shaw RM. Autoregulation of connexin43 gap junction formation by internally translated isoforms. Cell Rep [Internet]. 2013;5(3):611-8. Available from: http://dx.doi.org/10.1016/j.celrep.2013.10.009

65. Esseltine JL, Laird DW. Next-Generation Connexin and Pannexin Cell Biology. Trends Cell Biol [Internet]. 2016;26(12):944-55. Available from: http://www.sciencedirect.com/science/article/pii/S0962892416300745

66. Kotini M, Barriga EH, Leslie J, Gentzel M, Rauschenberger V, Schambon A, et al. Gap junction protein Connexin-43 is a direct transcriptional regulator of N-cadherin in vivo. Nat Commun [Internet]. 2018;9(1). Available from: http://dx.doi.org/10.1038/s41467-018-06368-x 
Figure 1. Limax innexin transcripts expressed in the central nervous system Alignment of deduced putative amino acid sequences of the Limax innexin homologs identified in the transcriptome of the central nervous system. The boxes show the four predicted transmembrane sites (TM1 to TM4), while the red arrows indicate two extracellular loops (EC1 and EC2). The asterisks indicate the extracellular cysteine residues in the extracellular loops, while the black arrow-heads indicate the P-X-X-X-W motif.

Figure 2. Phylogenetic tree of molluscan innexins

Phylogenetic analyses of molluscan innexins were performed using the maximum likelihood method with Homo sapiens pannexins as the outgroup. The percentage of replicate trees in which the associated taxa clustered together in the bootstrap test (2000 replicates) is shown next to the branches (only values over 50 are displayed). Sequence accession numbers are indicated next to species names. The names of Limax innexin homologs are in bold font.

Figure 3. Protein sequence alignment of molluscan innexin orthologs in Group 1 Alignment of putative amino acid sequences of Limax innexin 1 and 2 with orthologous innexin sequences. The boxes show the four transmembrane sites, while the asterisks indicate the extracellular cysteine residues. The potential S-nitrosylation sites are shaded in black. The phosphorylation sites are indicated with shading or box in magenta (protein kinase C), yellow (protein kinase A), blue (casein kinase 1), cyan (casein kinase 2), orange (P34cdc), and gray (protein kinase G). 
Figure 4. Protein sequence alignment of molluscan innexin orthologs in Group 2 Alignment of putative amino acid sequences of Limax innexin 3, 4 with orthologous innexin sequences. The boxes show the four transmembrane sites, while the asterisks indicate the extracellular cysteine residues. The potential S-nitrosylation sites are shaded in black. The phosphorylation sites are indicated with shading or box in magenta (protein kinase C), yellow (protein kinase A), blue (casein kinase 1), cyan (casein kinase 2), orange (P34cdc2), green (p38-mitogen-activated protein kinase), light green (proto-oncogene tyrosine-protein kinase Src), and gray (protein kinase G). Potential $\mathrm{N}$-glycosylation sites are underlined with bold red lines.

Figure 5. Protein sequence alignment of molluscan innexin orthologs in Group 3 Alignment of putative amino acid sequences of Limax innexin 5 with orthologous innexin sequences. The boxes show the four transmembrane sites, while the asterisks indicate the extracellular cysteine residues. The potential S-nitrosylation sites are shaded in black. The phosphorylation sites are indicated with shading or box in magenta (protein kinase C), yellow (protein kinase A), blue (casein kinase 1), cyan (casein kinase 2), orange (P34cdc2), and gray (protein kinase $\mathrm{G})$.

Figure 6. Protein sequence alignment of molluscan innexin orthologs in Group 4 Alignment of putative amino acid sequences of Limax innexins 6 and 7 with orthologous innexin sequences. The boxes show the four transmembrane sites, while the asterisks indicate the extracellular cysteine residues. The phosphorylation sites are indicated with shading or box in magenta (protein kinase C), yellow (protein kinase A), 
blue (casein kinase 1), cyan (casein kinase 2), orange (P34cdc2), green (p38-mitogen-activated protein kinase), light green (proto-oncogene tyrosine-protein kinase Src), and gray (protein kinase G).

Figure 7. Protein sequence alignment of molluscan innexin orthologs in Group 5 Alignment of putative amino acid sequences of Limax innexins 8 and 9 with orthologous innexin sequences. The boxes show the four transmembrane sites, while the asterisks indicate the extracellular cysteine residues. The potential S-nitrosylation sites are shaded in black. The phosphorylation sites are indicated with shading or box in magenta (protein kinase C), yellow (protein kinase A), blue (casein kinase 1), cyan (casein kinase 2), green (p38-mitogen-activated protein kinase), and gray (protein kinase G). Potential N-glycosylation sites are underlined with bold red lines.

Figure 8. Protein sequence alignment of molluscan innexin orthologs in Group 6 Alignment of putative amino acid sequences of Limax innexin 10 with orthologous innexin sequences. The boxes show the four transmembrane sites, while the asterisks indicate the extracellular cysteine residues. The phosphorylation sites are indicated with shading or box in magenta (protein kinase C), yellow (protein kinase A), blue (casein kinase 1), cyan (casein kinase 2), orange (P34cdc2), green (p38-mitogen-activated protein kinase), and gray (protein kinase $\mathrm{G})$. 
Figure 9. Protein sequence alignment of molluscan innexin orthologs in Group 7 Alignment of putative amino acid sequences of Limax innexins 11 and 12 with orthologous innexin sequences. The boxes show the four transmembrane sites, while the asterisks indicate the extracellular cysteine residues. The potential S-nitrosylation sites are shaded in black. The phosphorylation sites are indicated with shading or box in magenta (protein kinase C), yellow (protein kinase A), blue (casein kinase 1), cyan (casein kinase 2), orange (P34cdc2), green (p38-mitogen-activated protein kinase), and gray (protein kinase G). Potential N-glycosylation sites are underlined with bold red lines. 
Table 1 Summary of the predicted modification sites in the innexin orthologs of the seven groups.

The conserved modification sites between Limax innexin sequence and at least one other ortholog sequence are shown.

\begin{tabular}{|c|c|c|c|c|c|c|c|c|c|}
\hline & & PKC & PKA & CK1 & CK2 & SRC & $\operatorname{cdc} 2$ & N-glycosylation & S-nitrosylation \\
\hline Group 1 & $\begin{array}{l}\text { Limax Inxt } \\
\text { Limex } \ln x 2\end{array}$ & $\begin{array}{l}12, \text { T170, } \\
8324,8398 \\
\text { s12, T170, Ss38 }\end{array}$ & $\begin{array}{l}131, s 388 \\
\$ 131, s 368\end{array}$ & s2, T136 & 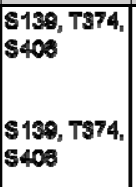 & . & . & . & . \\
\hline \multirow{2}{*}{ Group: } & Limex Inx3 & T153, 3337 & SS63 & $\$ 369$ & - & Y154 & - & N227 & - \\
\hline & Limex Inx4 & T155 & 8365 & - & - & - & - & $=$ & - \\
\hline Group 3 & Limax InxB & 812,8146 & $\begin{array}{l}\text { S187, T200, } \\
\text { T387 }\end{array}$ & $\$ 148$ & s18, s21 & - & - & - & - \\
\hline Group 4 & Limax Inx & 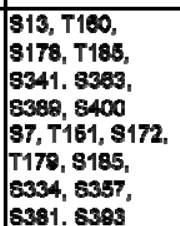 & 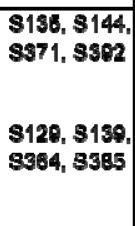 & 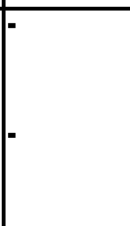 & $\begin{array}{l}\text { \$381, \$408 } \\
\text { \$374, } \$ 401\end{array}$ & $\begin{array}{l}Y 151 \\
Y 146\end{array}$ & 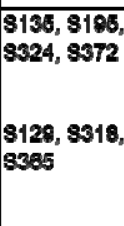 & - & $\begin{array}{l}\text { C182 } \\
\text { C178 }\end{array}$ \\
\hline \multirow[b]{2}{*}{ Group 5} & Limex Inx8 & T34, S152, S162 & & $F$ & S359, \$418 & - & - & - & $\mathrm{c} 200, \mathrm{C} 212$ \\
\hline & Limax Inx:8x1 & T18, S133, S143 & & - & $5340, \mathbf{8 3 9 8}$ & - & - & - & C181, C183 \\
\hline Group of & Limax $\ln x 10$ & $\begin{array}{l}\text { T173, T183, } \\
8986\end{array}$ & 8200 & - & $\$ 182$ & - & - & - & - \\
\hline Group 7 & LLmex $\ln \times 11 \times 1$ & $\begin{array}{l}\text { T147, } 8180, \\
T 200, T 326, \\
8331,8334, \\
8371\end{array}$ & $\$ 220$ & $\$ 146, \$ 160$ & T147, T421 & - & - & $\mathrm{N} 86, \mathrm{~N} 102$ & - \\
\hline
\end{tabular}


Table 2

Summary of identified Limax innexin circular RNAs (circRNAs) in the central nervous system. CDS, coding domain sequence.

\begin{tabular}{|c|c|c|c|}
\hline circRNA name & length & $\begin{array}{l}\text { Start-end position in the CDS } \\
\text { (total length of the CDS) }\end{array}$ & $\begin{array}{r}\text { Region out of } \\
\text { the CDS }\end{array}$ \\
\hline circlNX2a & 1395 & $1-1251(1251)$ & 144 \\
\hline circlNX2b & 801 & $282-1251(1251)$ & 0 \\
\hline circlNX2c & 1027 & $447-1251(1251)$ & 222 \\
\hline circINX3 & 1504 & $1-1269$ (1269) & 235 \\
\hline circlNX4 & 1965 & 215-1227 (1227) & 952 \\
\hline circlNX5 & 1192 & $1-1162(1224)$ & 30 \\
\hline circlNX6a & 633 & $458-1090$ (1242) & 0 \\
\hline circlNX6b & 1246 & $54-1242$ (1242) & 57 \\
\hline circlNX7a & 879 & $535-1224(1224)$ & 367 \\
\hline circlNX7b & 1235 & $1-1224(1224)$ & 11 \\
\hline circlNX8a & 1057 & 223-1275 (1275) & 4 \\
\hline circlNX8b & 1472 & $73-1275$ (1275) & 269 \\
\hline circlNX9x2 & 3234 & $223-1440(1440)$ & 2016 \\
\hline circlNX9x4 & 1410 & $26-1323$ (1323) & 112 \\
\hline circlNX11x1a & 795 & $265-1059$ (1353) & 0 \\
\hline circlNX11x1b & 784 & $312-1095$ (1353) & 0 \\
\hline
\end{tabular}


Limax Innexin 2

Limax Innexin 3

Limax Innexin 4

Limax Innexin 5

Limax Innexin 6

Limax Innexin 7

Limax Innexin 8

Limax Innexin 9x1

Limax Innexin 9x2

Limax Innexin 9x3

Limax Innexin 9x4

Limax Innexin 10

Limax Innexin 11x1

max Innexin $11 \times 2$

Limax Innexin 12partial
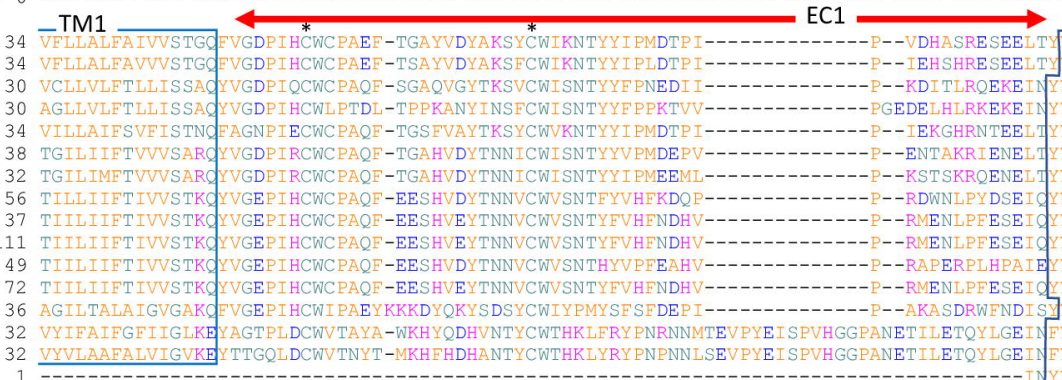

ENGGSGINLDKIVDMAEKTQLGSPDERDKTIDHISKYMDRWLETHREYHWNRLVRAKQALAKE-CC

-F-C-NIRAGTYLI

127

125

127

131

125
149

130

204

142

165

130

141
141

\section{8}

232

228

230

232

236

230

254

235
309

247
270

234

249

249
249
118

340

TM4

-WMICMGANTGN

\section{LQ1}

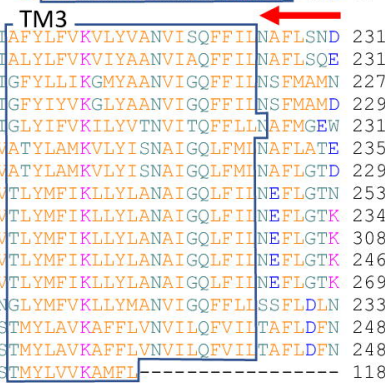

IWEWLVEVSTESCINLISWI YRVILKRNRAGYIRKYLKITNGIHT--G IWEWEFT TAVTACGSELSWT YYFLTNYNRYSFVKKYLATNVTIRN--K 336 LWEWEVEVAVCTCGNELFW]WRALFLSSRVAYIKKYMKLLDQIHG--E 338

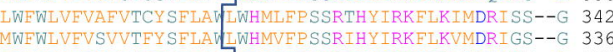
IWEWLVEVATLSAENELVW Y YMIERQHRLRYIKKFLRINDCYKS--E 360 IWEWLVFVAALSAENELI W] YTMVERQHRLRYLKKFLRINDCYKS--E 341 TWEWLVEVAALSAFNELIW IYTMVERQHRLRYIKKELRINDCYKS--E 415 I WEWLVEVAALSAFNELIW] YTMVERQHRLRYLKKFLRINDCYKS--E 353 IWEWLVFVAALSAFNELIW] YTMVERQHRTRYTKKFLRINDCYKS--E LWEWLILMVAEDSVNLIQWIRGLRPHSGESELVKYLHLMDVDT---K 33 EWEWMLILLVVTIYSEITW] TRILRTDQSVKEVTKYLSVLNEDGSLPQ
EWEWMLLLLVVTIYSEITWITRILRTDQSVKEVTKYLSVLNEDGSLPQ

340

RDSFARKEADEYLRDDG

339 EDKKLVHRFADQYLRDDGV

343 PDKKLATRETMEYLRHDG

337 PDKKLATRETMEYLRHDGV

361 LDKKMAVKECEQYLRQDG

342 LDKKMAVKECEOYLRODG

416 LDKKMAVKFCEQYTRQDGI
354 LDKKMAVKECEQYLRQDGI

377 LDKKMAVKFCEQYLRQDG

354 EGKRTVVTEVRDYLGN DGVELIRILATNTNDVVMSEIISSVWKRYIDYKNTAVKPEPPKE--PEPSINLTLDEIEMDPLSVPADTLDKIYGENDEHHI
354 EGKRTVVTFVRDYLGNDGVILIRILATNTNDVVMSELISSVWKRYI DYKNTAVKPEPPKE--PEPSINLTIDEIEMDPISSVADTLDKIYGENDEHHI

416

\section{${ }_{423}^{416}$}

$$
408
$$

\section{413}


99 - Lymnaea stagnalis FX181449

Blomphalaria glabrata Innexin unc-9-like isoformx 2 XP013082956.

Limax valentianus Innexin 2

Aolysia californica Pannexin 2 NP001191579

Group 1

Lottia gigantea hypothetic al protein LOTGIDRAFT 220783 XP009063028

Mizuhopecten yessoensis Innexin unc-g-like XP021370801.1

Crassostrea gigas Innexin unc- 9 XP01 1426033.

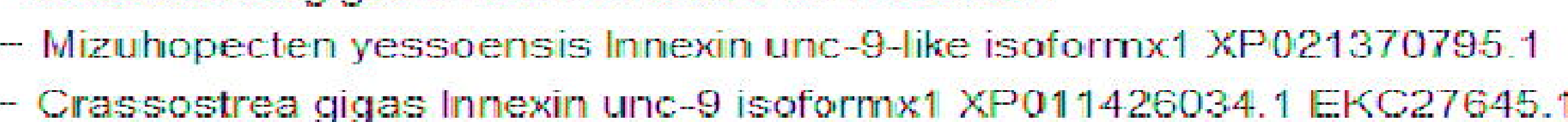

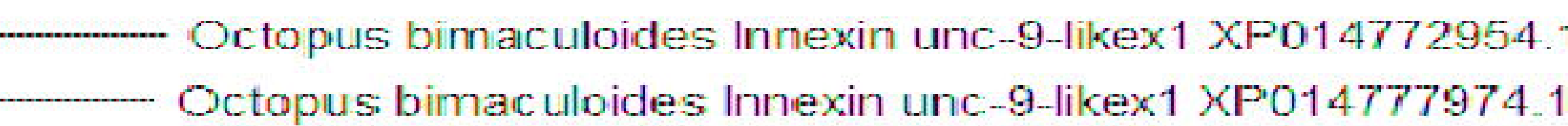

Octopus bimaculoides innexin unc-9-like XP014772958

100 - Limax valentianus Innexin 3

66 - Limax valentianus Innexin 4

LC Lymnaea stagnalis Innexin 3 . QIC555127.1

${ }_{98}-$ B Biomphalaria glabrata Innexin eat-5-like XP013085202.1

Lottia gigantea hypothetical proteir LOTGIDRAFT 200649 XP009048473,

Mizuhopecten yessoensis Innexin unc-9-ike Isoformx X XP021370802.1

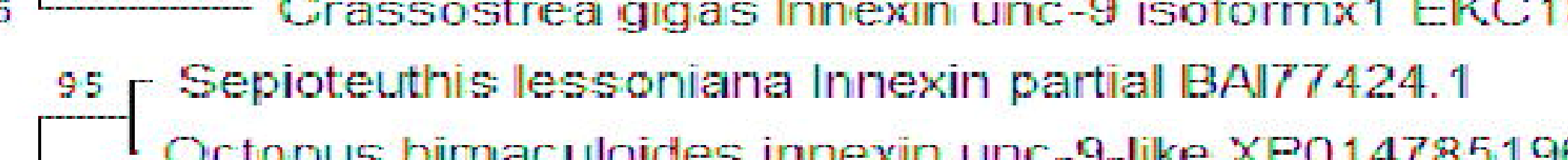

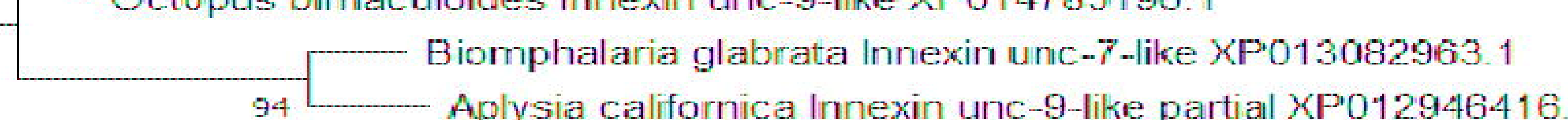

99 - Mizuhopectern yessoensis Innexin unc-9-like XPO21370812.1

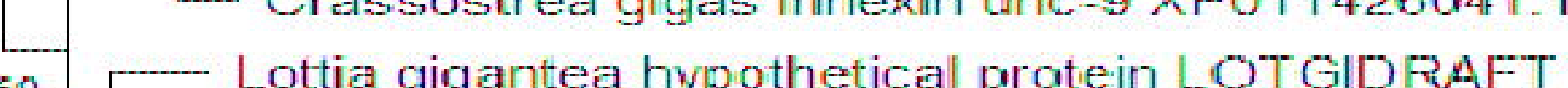

99 - Elysia chlorotica hypothetical protein EG

- Lymnaea stagnals innexin 1 alc55125.1

Blomphalaria glabrata innexin unc-9-1ike XP013082957.

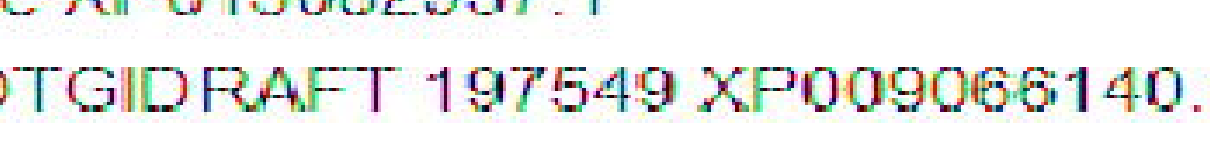
Aplysia californica Innexin unc-7-7-like partial XPV012946417 ${ }_{93}$ Elysia chlorotica hypothetical protein EGW08 009420 partial RUS82800

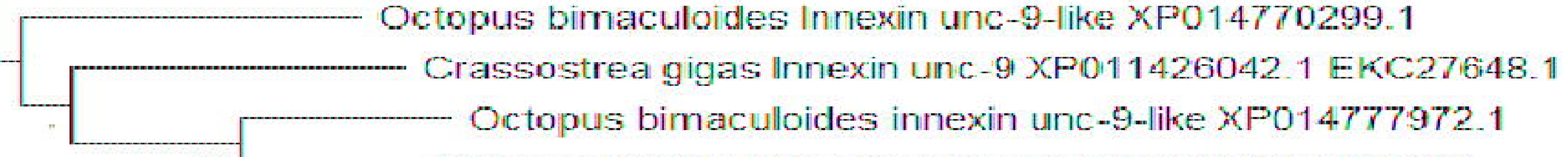

Octopus bimaculoides innexin unc--9-like XP014777973

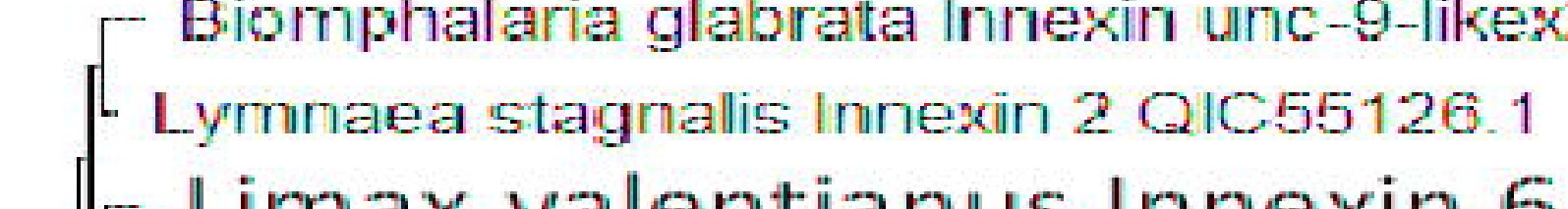

Limax valentianus Innexin 6

- Limax valentianus Innexin calfornica Pannexin 4 NP001191576

28. - Cplione limacina Pannexin 4 partial ABB872682.1

52. Elysia chloratica hypothetical protein EGW08 $003210 \mathrm{R}$

69. Lottia gigantea hypothetical protein LOTGIDRAFT 129454 XP

- Crassostrea gigas Innexin unc-9 isoformx 1 XP011441807.1

37. Mizuhopecten yessoensis Innexin unc-9-likex1 XP021346771.1 OWF 53666.1 Octopus bimaculoides tinnexin unc-9-inex $x$ p 014772989.1

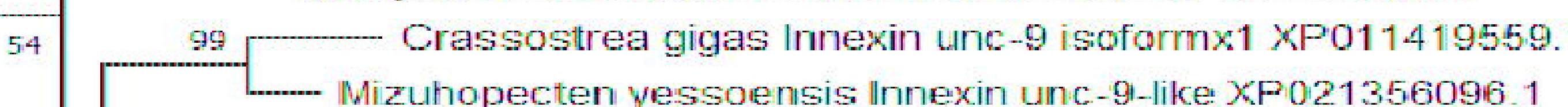

- Mizuhopecten yessoensis Innexin unc-9- -like isoformx 1 XP021353450 OWNF56107.

49 - Octopus bimaculoides Innexin unc-9-likex3 XP014767859.1

57 - Lottia gigantea hypothetical protein LOT GIDRAFT 170919 XP009045024.1

[ Pomacea canalculata innexn unc.9-

Portial RUS77811.1

01306327

Limax vallentianus Innexin 8

protein Pannexin AAF75839.

Aplysia californica Pannexin 1 NP001 1915:77.

Limax valentianus Innexin 9

\begin{tabular}{|l}
\hline Lottia gigantea hypothetic al protein LOTGIDFAFT 165688 XP009060973.1 \\
Lottia gigantea hypothetical protein partial LOTGIDRAFT 139782 XP009048110.1
\end{tabular}

Biomphalaria glabrata Innexin unc-9-like XP913077222

$99-[-$ Elysia chlarotica hypothetical protein EGWOS 023320 RUS68917.1

Aplysia californica Pannexin 5 NPDo01191595.1

- Pornacea canalic ulata Innexin unc-9-9-ike XP025084857.1

Aplysia californica Pannexin \& NP001191594.1
Limax valentianus Innexin 10

- $\square$ Biomphalaria glabrata Innexin unc-9-1ike XP 0130772261

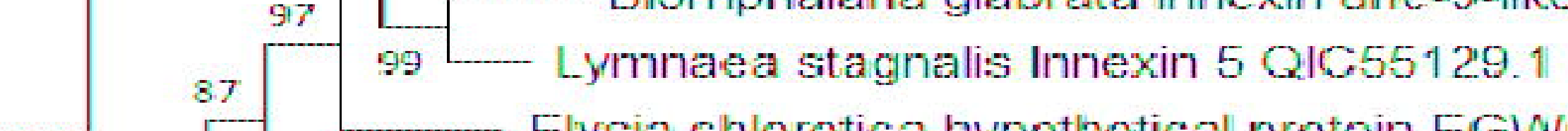

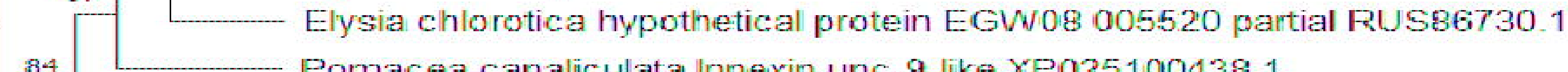

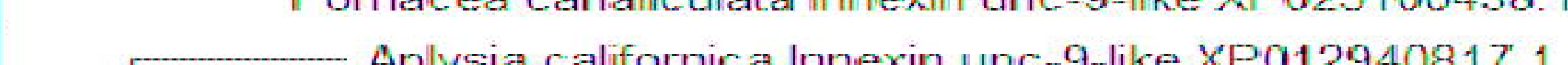

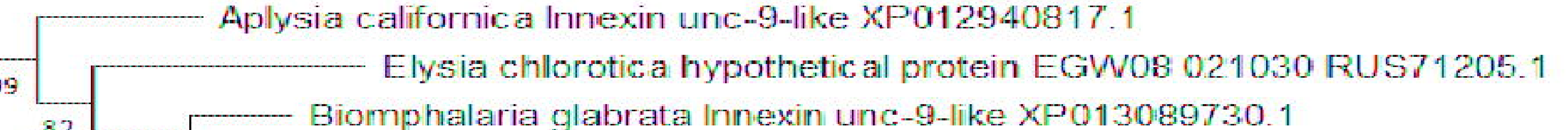

- Lymneas sta glabrata Innexin unc-9-9-like $\times$ -

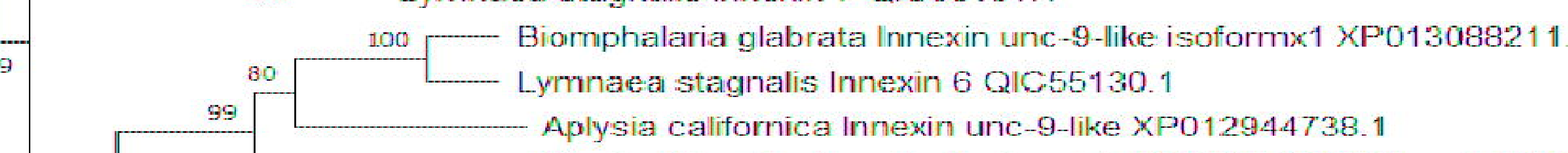

\begin{tabular}{|l} 
Aplysia californica Innexin unc-9-like XP012944738.1 \\
Elysia chlorotic a hypothetic al protein EGW08 005497 partial RUS86707-1
\end{tabular}

${ }_{100}^{100}\left[\begin{array}{l}\text { Pomacea canaliculata Innexin unc-9-likex } 1 \text { XP025089064 } \\ \text { P Pomacea canaliculata Innexin unc-9-likex } 1 \text { XP02511334 }\end{array}\right.$

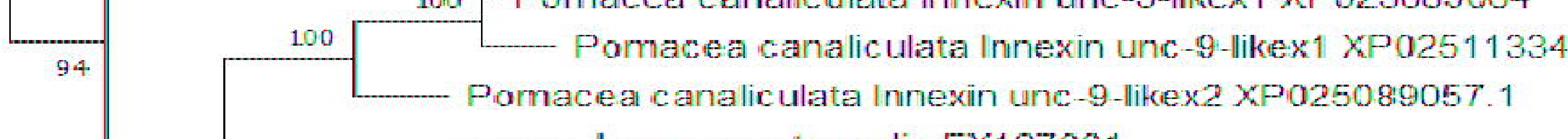

$96 \quad 56 \square$ Lymnaea stagnalis FX187001

Elysia chlorotica hypothetical protein EGW08 022284 partial RUS6995

${ }^{96} \quad$ Limax valentianus Innexin 12 partia

Group 7

Group 2

Group 3

Group 4

Group 5

Group 6

Aplysia californica Innexin unc-9-like XP005109439.2

Elysia chlorotica hypothetical protein EGW08 021564 partial RUS70674. Biomphalaria glabrata innexin unc-9-like $x$.

Pomacea canaliculata Innexin unc- 7 -like XP025085 451 -

95 - Crassostrea gigas Innexin 11 -like XP011422355.

92 Crassostrea gigas Innexin 3 EKC33152.1

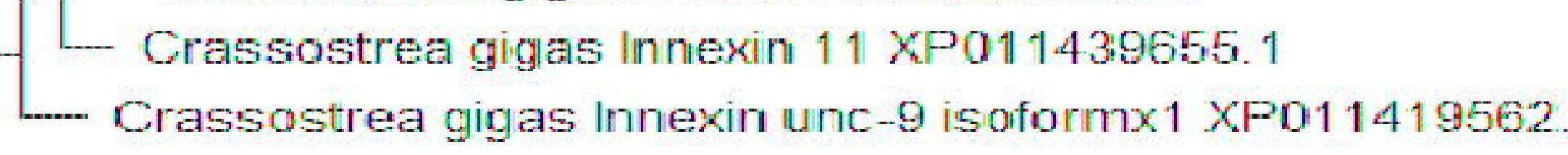

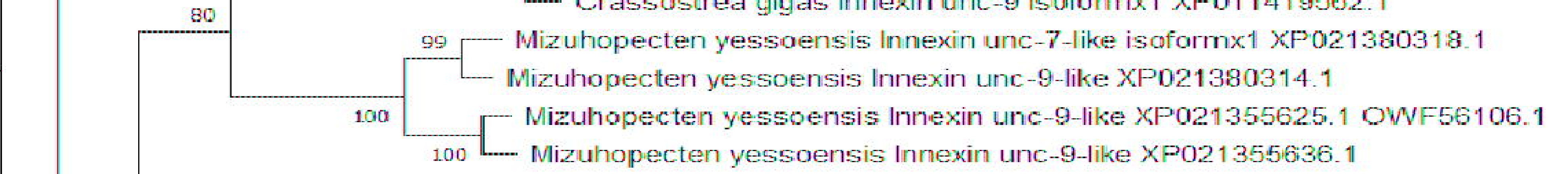

- Lottia gigantea hypothetical protein LOTOIDRAFT $168516 \times$ P 009064645.4

Lottia gigantea hypothetical protein LOTGIDRAFT 236164 XP009064646. 1

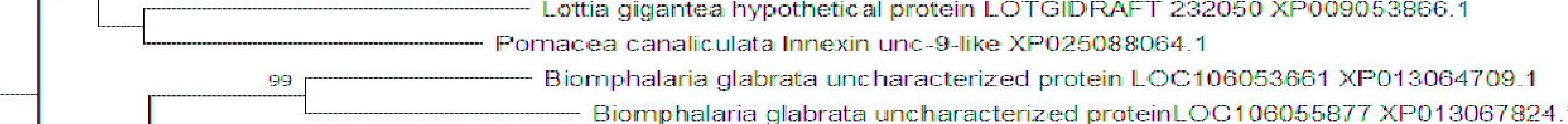

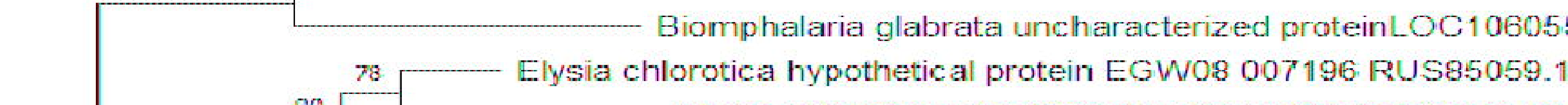

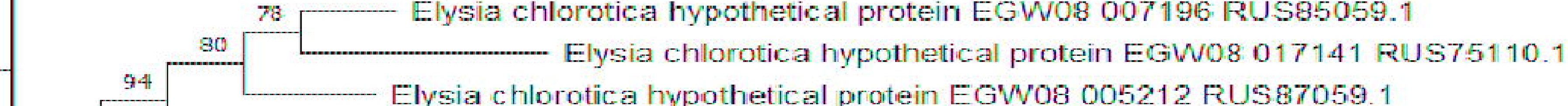

(1)

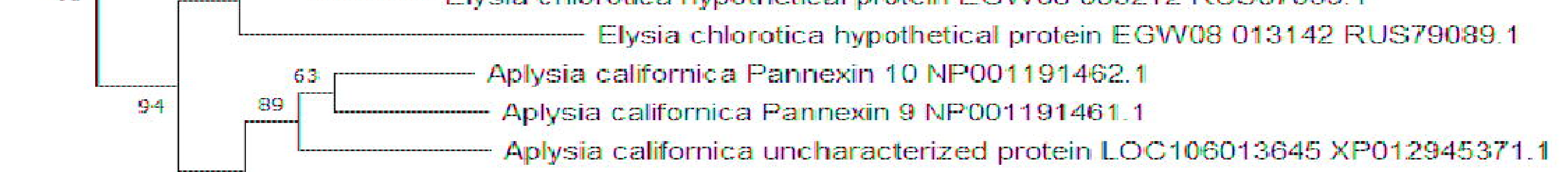
Aplysia calforrnica Pannexin 7 NP001191616.1

- - Aplysia californica ancharacterized protein LOC101847349 XP005101165.

A. Aplystac alifornica Pannexin 8 NPD0 1191596

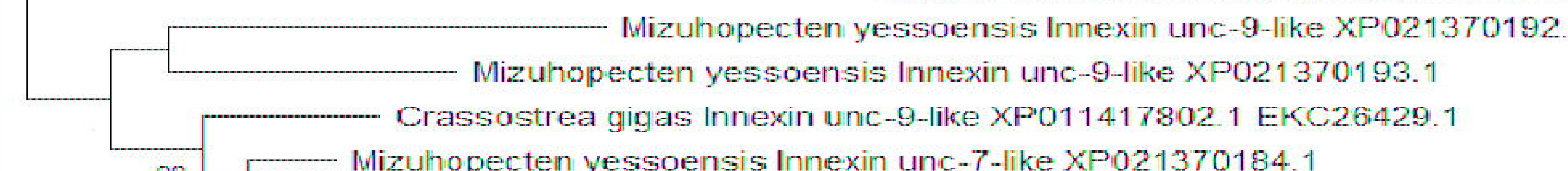

${ }_{99}-{ }_{91} \quad$ Mizuhopecten yessoensis Innexin unc-7-like XP021370184.1

Crassastrea gigas Innexin unc-9 XP019923536.1 EKC26845.1

$9 6 \longdiv { - C r a s s o s t r e a ~ g i g a s ~ I n n e x i n ~ u n c - 9 ~ i s o f o r m x ~ } 1$ XP011417806.2

Mizuhopecten yessoensis Innexin unc-9-9like XP021356092.1 OWF 49227

Mizuhapecten yessoensis Innexin unc-9-1-ike XP021356097.

izuhopecten yessoensis Innexin unc-9--ike XP021356091-1

exin 2EAW73494.1

- Horno sapienspannexin 3 EAWG67588.1 
1
54

WRLFNGGSGINLDKIVDMAEKTQI WRLENGGSG INLDKIVDMAER WRLFNGGSGINLDKIVDMAEK WRLFNGGSGINLDKIVDMAE 54 IHCWCPAEFTGAYVDYAKSYCWIKNTYYIPMDTP IPVDHASRESEELT

\section{GSILGGVP} IHCWCPAEFTGAYVDYAKSYCWI KNTYYIPMDTPIPTDHDNRESEELTY IHCWCPAEFTGAYVDYAKSYCWI KNTYY IPMDTP IP IEHANRESEEIT IHCWCPAEFTGAYVDYTKSYCWIKNTYF IPMDSAIPVEHVNRESEEIT IHCWCPAEFTGAYVDYAKSYCWI KNTYFIPMODS IPTDINVREDEEIT LGS

TM3

194 CNKRAGTYLT AFYLFVKVLYVANVISQFFII 194 CNKRAGTYLTALYLFVKVIYAANVIAQFFII 194 CNKRAGTYLTAFYLFIKVVYAANVIAQFFII

194 CNKRAGTYLIAFYLFVKVVYSANVIAQFFIL

194 CNKRAGTYLTAFYLFVKVVYAANVISQFFII

211 CNKRAGTYLTAFYLSIKVLYVVNVIGOFFLI

264 FKIRQLQNIQTWTVO *

264

IVQCVLPINLFNEKI F IVIWEWLVFVSTFSC INLLSWLYRVI LKRNRA GY IRKYLKIT

264 FKIRQLQNIQTWTVQCVLPINLFNEKIF IVIWEWLVLVATLTCLNLVSWLYRVMVKRNRATY IKKYLKIN

264 FKIRQLQNIQTWTVQCVLPINLFNEKI F IV IWEWLVFVATLTC INMV SWLYRVLFRRNRAGY IKKYLKIN

264 FKIRQMQNIQNWTVQCVLPINLFNEKIF IVIWEWLVFVATLSC INLVSWI YRVLFKRNRAGY IKKYLKIN

280 FRIRQLQNIQRWTVQCVLPINLFNEKIF IVIWEWLVIVSTLSCINMVAWEYRVLLKRNRGAY IKKFLKIN

334 NKLHTGFDRKLCHKFADEYLRDDGVFVIRVIAKNSTDLVATDLVDKLWKVYRDKKMMKEDEEPATLEA-T 334 NGIHTGFDKKLCOKFADEYLRDDGVFVIRVIAKNSTDLVATDLVDKLWKMYRNKKFKKNEDESPTIEP-

334 NELHTGFDKKLCQKFADEYLRDDGVFVIRVIAKNSTDLVATDLVDKMWKLYRAKRMKRNDDEPPAIEPTT 334 NELQSGFDKKLCQKFADEYLRDDGVFVIRVIAKNSTDLVATDLVDKMWKLYKSKRMKRNDDEPPAFDFST 334 NELQTGFDKKLCQKFADEYLRDDGVFVIRVIAKNSTDLVATDLVDKLWKLYKGKRMKKNDEEPPAFDFST 350 NELHTAQDKKDCVKFADQHLRDDGVFVLRVIAKNSTDLVVTDLVHVMEDLY--KKHQKPRREPNEYDP-E

403 IPISEKEKEAL-NPK

403 LTGSDKEKEAL-NSH

404 EPI-DKEKEAL-KPN

404 LPVSDKEKEAL-NQK

404 LPVNEKEKEAL-YPK 417 FP---NEKEALANDN 
Limax Innexin 3

Limax Innexin 4

Aplysia Innexin unc-9-like

Lymnaea Innexin 3

Biomphalaria Innexin eat-5-like Lottia LOTGIDRAFT200649
TM1

$*$ --MSLF SFASWSRVQGSRDDDWADRVSHLWTVVLLAAFTLLVSSAQYVGDPIQCWCPAQFTS------MALSLYGFASWSRLQGTKDDDWADRVSHLWTVGLLTFFAILVSTAQFVGDPIQCWCPAQFTGSYVSYTKN

0

1 MIGILSGLTSWSRLRGASDDDWIDRLNHIWTVVLLAIFTVVVSSAOYVGDPIHCWCPAQFTGAYVAYAKQ

TM2

69

61

V苂W

CW SNTYYFPNEDIIP SNTYYFPPKTVVPGEDELHLRKEKEIN

ICWI SNTYYIPMDDSIP--INIOERHEKEIS YY P YQWV
-EWI NLMFQALMFKVPNZIWRLLNGVGGLNMDRLVH $-----------------------------$ $---$ PIIFLFOALMFKL PNI IWKMLNDSGGLNIDKI IS ICWISNTYYVPMDNEIP--VQITERQDREIT

YOWTPTIFTEMATMEKIPNI MVWKMLNSTGGLNVDRLVS

137 LAESAQISKSEDREKMTYQVAKYIDRWLKAHRQYHYNLLVRLRQRFANVFCFWFAKREGKFLT GFYLLIK

139 LAESAQLGNSEDREKVTHQVAKYIDRWLKAHRQYKYNILVRLQQRCANVFCFWFAKREGKFLTGFY IYVK

86 LAESTQMGKPEDREKTIYQVARYLDRWLKAHRQYRFNLLVRMRQRLSSVFCFWLAKREGRFLTGFYLFIK

139 LAESTQLGKPEDREKF I YQVAKYIDRWLKAHRQYHYNLLVRLRQRFANVFCFWEAKRDGKYLTGFYLFIK

20 LSESTQIGKQEDREKMTYQVAKYLDRWLKAHRQYHYNLLVRLRQRF SNVFCFWFAKRDGKYLTGFYLFVK

139 MTADMQICSPNQRDENIRHIAKYMDRWLKANRQYHFNI IVRARQKISGICCFWFGKREGTYITGFYLLVK TM3

207 GMYAANVIGQFFIINSFMAMNFTVYGFEVLYKLFNEGEFNDSPRF PRVTLCDFELRQLSNLHRYTVQCVI

209 GLYAANVIGQFFIINSFMAMDFSVYGFEVLYKLFNEGEFRNSPRF PQVTLCDFVIRQMSNSQRYTTQC

156 LLYVVNSICQFFIINGF LSMDFNVYGFEMMRLLAENGELKDSPRF PRVTLCDFEIRQLQNLQRYTVQCVL

209 LLYVANVIFQFFIINFFLSMDYSVYGLEVIQSLIKTGEFKDSPRF PRVTLCDFEIRQLQNLQRYTVQCVI

90 FLYVANVIFQFYII LLYVLNIIGQFYLI

NHF LAMNYSVFGLEVVEALVKEGSYTDSPRF PRVTLCDFEIRQMANVQRYTVQCVL TM4

277 PINLFNEKIFI ELWFWYFVIAVIACGSYLLWIYYFLIGYNRYRFVKKYLMINDALRNEKDSKFARKFADE 279 PINIFNEKIFI FLWFWFFIIAVIACGSFLSWLYYFLINYNRYSFVKKYLAINVTIRNKQDSQLAHKFADE 226 PINLFNEKIFIFLWFWLLIVAIVACGSYVSWLYYILVGENRYRYAKKYLVINDHIHNKMDSKLARKEANE 279 PINLFNEKIF IVLWFWYLLVAVITTFNYLSWIYHVLFGGNRYKYVKRFLKLGDNLSSKSDSKLAKKFANE

160 PINLFNEKIF I FLWFWYLLVSAVTVFNYLAWLYQILLGGNRYRYVKKYLKLGDNIRNKTDAKLAK----279 PINLFNEKIF IE IWEWLFFIAVLTS INYVNWIYHVLVKQNRAKYVKKYLKLNDEIRSSGDLKLCRKFADE

347 YLRDDGVFVLRVIAKNSSELVLTDLICILWSLYRENPLT--IKQNETRNRKMKSNGKVLSSTLERDVDDN 349 YLREDGVFILRIIAKNSSELVLTELISNLWTLYRENPIT--IKPYERKY----------------IDDN 296 YLRDDGIFVLRVVSKNSSELVLTDLVKDLWRLYKENPVD--NKLRKKDMRSDVINGNVKPTT---EMDEE 349 YLRDDGVFVLKIVAKNSSDLVLNDLVNYLWMFFKDNPHV--ATAYEKKLRDAKMNGKHAISTL--EMDPE 225 34 YLRDDGVFVLKIVSKNSSEIVLKDLVLYLWRLYKSDPKT $-Y Q S S L$

415 NSSDRFSHN

400 DAMERCGHI

361 EMLEFGDHV

415 ELREINHKL

$229--------$

403 DVKFATF--

68
60
70
0
70
136
138
85
138
19
138

206 208 155 208 89 208 276 278 225 278 159 278 346 348 295 348 224 348

414 399 360 414 402 


\section{Limax Innexin 5}

Lymnaea Innexin 1

Biomphalaria Innexin unc-9-like

Elysia EGW08_009419

Aplysia Pannexin 3
1 MSVSAILGGEASYSKFTSNSDDDWVDFLNHLYMVI

1 MSVSAILGGWA SYSKLTSSNDDDWVDALH

1 MSVSAILGGWTSYSKLT SNNDDDWVDA LNHLYTVILLA IFTVFISTCOYAGNPIECWCPAYFTGSYVSYT

1 MSVIALLG-FA.SYSKF ISSSDDDWADA LNHLWTVLILALFAVF ISGGQYVGNP IECWCPAHF TGTFVAYT

1 MSVSAILGGEA.SYSKLTSSNDDDWVDRLNHLYTVILLAIFAVFISGGOYVGNP IECWCPAHFTGSFTAYT

71 KSYCWVKNTYYIPMDTPIPIEKGHRNTEELTYYOWVPIILLFMAFLFKFPAIMWRMLNGGSGINIDKIVT 140

71 KSYCWVKNTYY IPLDTPIPVAKDERSSEEITYYQWVPI I LLFMAFLFKF PALVWRMFNGASG INMDKIVT 140

71 KSYCWIKNTYYIPIDEQ IPSSKHDRTSEEI TYYQWVPI I LLFMAFLFKF PAI LWRMFNGGSG IN INKIVD 140

70 KSYCWVKNTYY I PMDNQ I PTDRTHRDSEEL TYYQWVPI ILMFMAF LFKF PAIVWRMFNGASG INMDKIVA 139

71 KSYCWVKNTYY I PMDTP IPVDRDNRNSEELTYYOWVPI ILLEMAFMFKFPALLWRMFNGGSG INMDKIVT 140

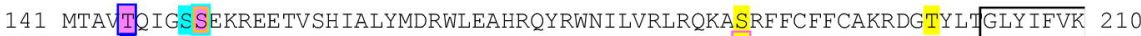
141 LTATTQIGAQDKRDETVSH IA IYMDRWLEAHRQYRFNIMVRMRQKA SRFFCFFCAKRDGTF L I GLY IFVK 210 141 MTSAVQIGGQDKRDE TVNH IA IYVDRWLDAHRQYRFNIVVRMRQKISKFFCF LCAKRDGTY L I GLY IF IK 210 140 MTSATQIGPAEKRIETVGH IANYMDRWLEAHRQYKWNIVVRMRQKN SRFFCFLCAKRDGTF L I GLYLFCK 209 141 MTAGTRIGASEKREETVGH IAKYMDRWLEAHRQYRYNALVRMRQKASRVI

211 ILYVTNVITQFFLLNAFMGEWYNLYGFEVLSGLANDHYWRESPRF PKVTLC

CFLCSKRDGTYLT TLL

$*$

GLYIFVK

$*$

211 ILFVVNVITQFFLLN AF LGGWYNLYGFEVLEGLATDHYWRDSPRFPKITLCDFEIRQLQNIQTYTVQCVL 280

211 LLYVVNVVTQFFLLN AFMGSWYNMYGFEVIGGLASDHTWPDSPRFPKITMCDFEIRQLQNVQPHTVQCVL 280

210 LLFVVNI ICQFFLLN AFMGGWYNLYGFEVIDGLTKDHYWRDSPRFPKVTLCDFEIRQLQNIQTFTVQCVL 279

211 VLYVVNVIIQFFLLNGFMGDWYNLYGFEVLDGLANDRYWRDS PRFPKVTLCDFEIRQLQNIQTHTVQCVL 280

TM4

281 PINMFNEKIFIFLWFWFVFVAVCTCGNFLFWIWRALFLSSRVAYIKKYMKLLDQI HGEE DKKLVHRFADQ

281 PVNLFNEKIF IFLWFWFVFVAVCTCGNE LFWIWRALFRSNRASY I KKYMKVLDQI HGEEDKKLVRRFADQ

281 PINLFNEKIFI I IWFWFVEVA ICTAGNE LFWIWRALFRSNRASY IKKYLKL LDQIKGEEDKMLLRKEADQ

280 PINLFNEKIFI FLWFWFVVVACA TVGNF LFWVWRALFATSKVGYIKKYMRA LDQ I HTEEDKRWVRKFADQ

281 PINLFNEKIF LELWFWEVEVAVCTCGNE LEWIWRALFLRNRVAYVKKYLKI LDEIRSEEEKKLVRKFADQ

351 YLRDDGVFIMRLIARNTNDILLSDILGKMWDIYKNKPAIKKSREAENDTFGAVDSQA--

351 YLRDDGVFILRLIARNTSDILLGDIILKL---------RVTPESLHAHFW--------

351 YLRDDGVFILRLIARNTSDILLSDIVLKLWSTEKNKPGVKKQQEDEMSKFT--DSQA--

350 YLRDDGVEIFRIIARNSSDILLSDIVSKMWELYRNKPQ IRKSLDAENDNYGRKDDETLA

351 YLRDDGVEILRIIARNTSDILLSDIVRKLWGIYKDKPLIKKSLDAENENYGP-DSQA--
350

350

349

350

407

391

405

408

406 
Clione Pannexin 4 partial

Aplysia Pannexin 4

Elysia EGW08_003210

Lymnaea Innexin 2

Biomphalaria innexin unc-9-likex1

Pomacea innexin unc-9-like

Lottia LOTGIDRAFT129454

Crassostrea innexin unc- $9 \times 1$

Mizuhopecten innexin unc-9-likex1

Octopus innexin unc-9-likex1

1

1

1 1 1

TM1

22 VRNDDDLNDF $\overline{\text { VNHLYTTGILIIFTVVVSARQ }}$

16 VRNDDDLNDR VNHLYTTGILIMFTVVVSARO

16 VRNDDDLNDAANHLYTTGILIIFTVVVSARO

22 VRNDDDLNDA VNHLYTTGILIIFTVVVSARO

48 VRNDDDLNDA VNHLYTTGILIIFTVVVSARO

16 VRNDDDLNDA VNHLYTTGILIIFTVVVSARO

23 VRNDDDLNDAVNHLYTTGILIIFTVVVSARO

18 VRNDDDLNDA LNHLYTTGILIIFTVVVSARQ
16 VRNDDDLVDA LNHLYTTGILIIFTVVVAR

81 VRNDDDLIDA LNHFYTTGILIIFTVVVSARC

20 VRNDDDIVDAVNHFYTTGIFIIFTVVVSARO

25 VRNDDDLIDRMNHLYTTGILIIFTVVVSARd

TM2

100 IENELTYYYQWVPMLLIQALMFYIPC

94 QENELTYYQWVP IMLLIQALMFYIPCI

94 SETELA

100 METQLTYYQWVPVMLLIQALLFYIPC

126 KQHELT YYOWVPVMLLVQALMFYLPCI

94 TENELTYYQWVPVMLLIQALMFYIPCI

101 RENELTYYQWVPVMLLIQALMFY IPC

96 NERELTYYQWVPVVLLLQALMFYIPCI

94 KERELNYYQWVPVVLLIQALMFYLPC

161 REKELNYYQWVPVMLLIQALMFYIPCI

100 KEKE LN YYQWVPVMLLVQALLFYCPCH

103 KEKELGYYOWVPVVLLLOALLFYLPC

$\begin{aligned} 180 & \text { HRC } \\ 174 & \text { HRC } \\ 99 & -- \\ 180 & \text { HRC } \\ 206 & \text { HRC } \\ 174 & \text { HRC } \\ 181 & \text { HRC } \\ 176 & \text { HRC } \\ 174 & \text { HTC } \\ 241 & \text { GTC } \\ 180 & \text { GWCC } \\ 183 & \text { HSC }\end{aligned}$

TTMRHISAKISLLCGRRYGNYLV $\sqrt{\bar{A}}$ TMIAM

WRLLNGCSGINVDRIVSLASDAOY EAPEVRIRT IKYVVRH IDRCLDNQRESR IWRLLNGQSGINVDRIVSLASDACYEAPEVRIRTIKYVVRH IDRCLDNQRESR

IWRLLNGQ SGINVDRIVSLASDAQYEEAPEVRIRTIKYVVRH IDRCLDNQRESR LWRLLNGH SG INVDR IVSLASDACYEAPEVRMRT I KYVVRH IDRCLDNQRESR VWRLLNGQSGINVDRIVSLASDAQY EAPEVRIRT I KYVVRH IDRCLDNQRESR LWRLFNGC SG INVDR IVSLASDAQY EAPEVRIRT I KYVVRH IDRCLDNQRESR LWRLLNGC SGINVDR IVSLASEAQY ESPEVRMRT I KYVVRH IDRCLDNQRESP IWRLLNGC SG INVDR IVSLASDACY ESPEVRMRT I KYVVRH IDRCLDNQRESR IWR ILNGQ SG INVDR IVSLGSNAQFESPETRVRT IKYLVKHVDRCLSNQRDTR IWRLMNGN SG INVDRIVSLAGDACYESPDSRIRT IKYLVRHMDRCLDNQRDTR IWRLLNGCSGINVDRIVSVASDACY ESPENRTRN I KYVVRHMDRCLDNQRETR TM3

260 PRVTMCD VTMRH I LSAKLSLLCGRRYGNYLY A ATYLAMKVLYISNA IGQLFMI

254 99

260

286

254

261

TTLRH ILSAKLNLLCGRRYGNYLV VTLRH ILSAKLSLLCGRRYGNYLY VTLRH ILSAKLSLLCGRRYGNYLI VTLRHVLSVKMSLLCGRRYGNYLI VKLRHVLSAKI SI LCGKRYGNYLI VKLRH I LSAKISLLCGKRYGNYLT
VQLRH I LSTKLSILCGRRYGNFLV VTLRHILSAKLSLICGRRYGNYL VRLRHILSANLSLLCGR * * * LVA TYLAMKVLY I SNA IGQF FMM STYLAMKILY ISNG IGQLFMI
AVYLAMKVLY ISNA IGQLEMI SVYF LMKVLY I SNAVGQLFMI NAB I YF LMKALY IANA IGQLELI IGQLFMI

TM4

263 PRVTLCDFEIRQLPNLNRYTVQCVLPINLFNEK IY IELWFWLVEVSMLSCYSFATH

340 SSGPDKKLATRFTMEYLRHDGVFTLRLVGKNSSDIVVAEIVSGLWDLYRSKKSIQIRNLAS----LPSNGHESDGEDV

\begin{abstract}
GSGPDKKLATRFTMEYLRHDGVFTLKLVGKNSSDIVVAE I I SGLWDLYRSKKS IQIRNTTS
\end{abstract}
PRVTMCDFEIRQMTNKHNYSVQCVLPINLFNEKIYI

PRVTICDFDIRQMSNKHHYSVQCVLPINLFNEKIYI

PRVTMCDFDIRQMTNNHHYSVOCVLPINLENEKIY IE LV

PRVTMCDFEIRQMTNNHRYTVQCVLPINLFNEK IYI

PRVTLCDFQIRQVTNLQQYTVQCVLPINLENEKIYI

PRVTLCDFQIRQITNVQQYTVQCVLPINLFNEKIYI

GSGPDKKLATRFTMEYLRHDGVFTLKLVGKNSSDIVVAE IMSGLWDLYRSKKSIQIRNTTS----LPSNGHESDGEDV GSGPDKKLATRFTMEYLRHDGVFTLRLVGKNSSDIVVAE IVSGLWDLYRSKKTIQLRNTVSSANMS|PNGGPESDGEDV GSGPDKKLATRFTMEYLRHDGVETLRLVGKNSSDIVVAE I ISGLWDLYRSKKSIQIRNTAS----LPSPGHESDGEDV GSGPDKKLATRFTMEYLRHDGVFTLRLVGKNSSDIVVAE I ISGLWDLYRSKKSIQIRNT------LPSNGHESDGEDV GTGPDKKLATRFTMEYLRHDGVFTLRLIGKNSSDIVVAE IVSGLWDMYRSKKS IQIRNTT-----LPTNGHESEGEDV GSGPDKKLASRFALEYLRHDGVFTLRLIGKNSSDIVVAE IVSGLWDIYRGKKSIQIRNTSI------NNGHE-EVEDV GTGPDRKLAARFVMDYLRHDGVFTLRLIGKNSSDIVVAE IVSELWDMYRSK

IQIRTNSQ GSTPDKKLANRFTVEYLRHDGVFTLRLIGKNSSDIVVAE IVSGLWDMYRSKKSIOIR---
21
15 15 
Limax Innexin 8

Limax Innexin 9x1

Limax Innexin 9x2

Limax Innexin 9x3

Limax Innexin 9x4

Aplysia Pannexin 1

Clione gap junction protein

Lymnaea Innexin 4

Biomphalaria Innexin unc-9-likex1

Elysia EGW08_014428 partial

Pomacea Innexin unc-9-likex4

Lottia LOTGIDRAFT70919

Octopus Innexin unc-9-likex3

Mizuhopecten Innexin unc-9-likex1
1

35 YARLKGRYDDDWIDR $\overline{L N}$ TMLYTT

16 YARLKGRYDDDWIDA

LYTTI LII IFT IVVSTK

90 YARLKGRYDDDWIDALNHLYTTI ILI IFT IVVSTK

28 YARLKGRYDDDWIDP

51 YARLKGRYDDDWIDP

16 YARLKGRYDDDWIDR

37 YARLKGRYDDDWIDAI

LNHLYTTI ILI IFT IVVSTK

NHLYTTI ILI IFT IVVSTKO

SHLYTTI ILI IFT IVVSTKO

17 YARLKGRYDDDWIDA LNHLYTTI ILI IFT IVVSTK

35 YARLKGRYDDDWIDA LNHLYTTI ILI IFT IVVSTKO

11 YARLKGRY DDDWIDA LNHLYTTI ILI IFT IVVSTKO

35 YARLKGRYDDDWIDP LNHLYTTI ILI IFT IVVSTKQ

13 YARLKGRYDDDWIDR LNHLYTTI ILI IFT IVVSTK

21 YARLKGRY DDDWIDR LNHLYTTI IF I IFT IVVSTKO

33 YARLKGRYDDDWIDALNHLYTTI IFI IFT IVVSTK

123 TMYYWVMI LLFQALIFKVPC 14 WRI LTASAGVNLDKIVTLAAE TAYVAPDDRDRT IKH IVRYMDRWIENAREYRS

104 OYYQWIPMILLFQAVLEKVPCI

178

116

139

104

125

107

123

99
122

101

109

121

YYYWIPMI LIFQAVLFKVPCII

LWR WRI ITASAGVNLDKI VTLAAE TAYVAP DDRDRT I KH IVRYMDRWI ENAREYRSG
WRI ITASAGVNLDKIVTLAAETAYVAP DDRDRT I KH IVRYMDRWI ENAREYRSG

YYQW I PMI LL FQAVLEKVPC

OYYQWVPMI LLFQALLFKVPC

YYYQWVPLI LLFQALLFKVPC I

WRI LTASAGVNLDKI VTLAAETAYVAP DDRDRT IKH IVRYMDRWI ENAREYRS

RILTA SAGVNLDKI VTLAAETAYVAP DDRDRT I KH IVRYMDRWI ENAREYR.

LWRI LTASAGVNL DKI VTLAAETAYVAP DDRDRT I KH IVRYMDRWI ENAREYRS

YYQWVPMILLFQALMEKVPC

LWRI

LWRI LTA SA GVNL DKI VTL AAE TAYVAP DDRDRT I KH IVRYMDRWI ENAREYRS

LWRILTASA GVNLDKIVTLAAETAYVAP DER DRT I KH IVRYMDRWI ENAREYRS

YYQWVPMI LLFQALLEKVPCI

YYQWVPMI LIFQALLFKVPC I

Ling

WRI LGASGGVNLDKI VTLAADTOFVAPEDRERT I KH IVRYMDRWLENAREYRS

TM3

213 CIVWGKRYGNYLY

194 CIVWGKRYGNYLV

268 CIVWGKRYGNYLY

206 CIVWGKRYGNYLV

229 CIVWGKRYGNYLT

194 CIVWGKRYGNYLT

215 CIVWGKRYGNYLY

197 CIVWGKRYGNYLY

213 CIVWGKRYGNYLV

189 CIVWGKRYGNYL

212 CLVWGKRYGNYLV

191 CIVWGKRYGNYLY

199 CIVWGKRYGNYLF

211 CIVCGKRYGNYI

TLYMF IKLLY LANAIGQLF I TLYMF IKLLY LANAIGQLF II TLYMF IKLLY LANAIGQLF I TLYMF IKLLYLANAIGQLF II TLYMFIKLLYLANAIGQLF I ILYMF IKLLYLTNAIGQLF II TLYMF IKLLY LSNAVGQLF II TLYMF IKLLYLANAIGQLF I TLYMF IKLLY LANAIGQLF II I LYMF IKLLYLGNAIGQLF I I LYMF IKLLY LANGIGQLF II I IYMVIKIFYMGNAVGQLF II

\section{TM4}

303 PINLFNEKIEIFIWEWLVFVATLSAFNFLVWI 284 PINLFNEKIFI FIWEWLVFVAAL SAFNFLIWIY

358 PINLFNEKIFIFIWFWLVFVAAL SAFNFLIWI

296 PINLFNEKIFI FIWEWLVFVAAL SAFNFLIWI

319 PINLFNEKIFIFIWEWLVFVAALSAFNFLIWI

284 PINLFNEKIFI FIWEWLVFVATL STFNFLIWV

305 PINLFNEKIFIFIWEWLVFVATLSTFNFLIW

287 PINLFNEKIFI FIWEWLVFVATLSTFNFLIWI

303 PINLFNEKIFIFIWFWLVFVATLSTFNFLIW

279 PINLFNEKIFIFIWEWLVFVATL SSFNFLIWI

302 PINLFNEKIFI FIWEWLVFVSTLSAANFL IWT

281 PINLFNEKIFMFIWEWLVFVSTL SAGNFLIWT

289 PINLFNEKIEI IWEWLVFVSTF SAGNFLIWH

301 PINLFNEKIFIEIWFWLVVVSVISSANFIVWD

393 LVSELILQLWNHYRNKPLFRHANQVSDDNSNV

374 LVSELILQIWNHYRNKPLFRHTNQVSDDNSNV

448 LVSELILQIWNHYRNKPLFRHTNQVSDDNSNV

386 LVSELILQLWNHYRNKPLFRHTNQVSDDNSNV

409 LVSEL ILQIWNHYRNKPLFRHTNQVSDDNSNV

374 LVSELILQLWNHYRNKPLFRHANQISDDNSNV

395 LVSELILQLWNHYRNKP LFRHANQISDDNSNV

377 LVSELILQLWNHYRNKPLFRHANQISDDNSNV

393 LVSELILQLWNHYRNKPLFRHANQISDDNSNV

369 LVSELILQIWNHYRNKPLFRHANQISDDNSNV

392 LVSELILQLWNHYRNKPLFRHANQISDDNSNV

371 MVSELVLQLWNFYRNKPLFRHANQISDDNSNV

379 LVSELVLQLWNHYRNKPLFRHANPISDDNSNV

391 LVSEIILQLWNHHYRNKPLIKHANQI SDDNSNV

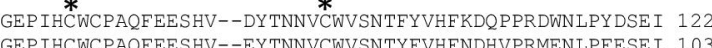
EP IHCWCPAQFEESHV--EYTNNVCWVSNTYFVHFNDHVPRMENLPFESEI 17 GEPIHCWCPAQFEESHV--EYTNNVCWVSNTYFVHFNDHVPRMENTPHPA I 115 P IHCWCPAOFEESHV--EYTNNVCWVSNTEWVHFKNOPPRDWNLPYDSE 138 GP IHCWCPA CWVANTEYVPEEHALPRGPARPSKAE I 98 CPAOFEDSHV--DYTNNVCWISNTYFVSMEHVIPQHDAPKKEKEI 100 EP IHCWCPAQFTSGHR--DYANNVCWISNTYYVPEEERIPLHREGKQQKEI 108

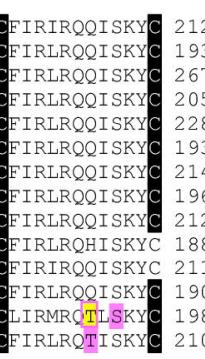
NEFLGTNENVYGEEVMDHLARGETWSESPREPRITHC IEFLGTKFNVYGEEVMDHLARSESWSESPREPRITH EFLGTKFNVYGEEVMDHLARSESWSES PREPRIT EFLGTKFNVYGEEVMDHLARSESWSESPREPRITH EFLGTKENVYGEEVMDHLARSESWSESPREPRITHC

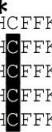
TRE NEFLGTNFNVYGEEVMDHLARGESWSESPREPRITHCFFK IRQMTNVHDYTVQCVL NEFLGTNFNVYGEEVMDHLARGESWSESPREPRI THCFFK IRQLTNVHDYTVQCVI NEFLGTNFNVYGFEVMDHLARGENWSESPREPRI THCEFKIRQITNVHDYTVQCVL NEFLGTNENVYGFEVI DHLARGESWSESPKFPRITHCFFKIRQLQNVHDYTVQCVL NEFLGTNYNVYGEEVMDHLAKG I DWTES PRE PRVTHCYFE IRQMQNVHQYTVQCVL NEFLGTNYNVYGEEVMDHLARG IDWIDSPREPRVTLCDFRIRQMQNVHDYTVQCVL NEFLGTNYNLYGFEVLSHLANGDDWTESPRE PRVTMC DFE IRQMQNVHKYTVQCVI NEFLGTNYNA YGLEVL DHLANG I DWKESPRE PRVTLCDFR IRKLATVQDYTVQCVI

$$
\begin{aligned}
& \text { IMIFRQHRLRY LKKFLRINDCYKS } \\
& \text { TMVFROHRLRY LKKFLRINDCYKSE }
\end{aligned}
$$
TMVR HRLRY LKKF LR INDCYKSEL DKKMAVKFCEQY LRQDG I FVL RLVGKNAND TMVFRQHR LRY LKKF LR INDCYKSEI DKKMAVKFC EQY LRQDG I FVLRLVGKNANDV YTMIFRQHRLRY LKKF LR INDCYKSEI DKKMAVKFCEQY LRQDG I FVLRLVGKNANDV TMIFRQHR LRY LKKF LR INDCYKSEF DKKMAVKFCEQY LRQDG I FVL RLVGKNANDV TMIFRQHRLRY LKKF LR INDCYKSEL DKKMAVKFCEQY LRQDGI FVL RLVGKNANDV TMI FRQHRLRY LKKF LR INDCYKSEL DKKMAVKFCEQY LRQDG I FVL RLVGKNANDV TM I FRQHRLRY LKKFLR INDCYKSEL DKKMAVKFCEQY LRQDG I FVLRLVGKNANDV TMIFRQHR LRY LKKF LR INDCYKSELDKKMAVKFAEQY LRQDG I FVLRLVGKNANDV TMIFRQHRLRY LKKF LRVNDCYKSELDKKMA I KFGEQY LRQDG I FVLRLVGKNANDV AMVFRQHRIRY LKKF LRVNECYKTELDKKMAVKFADQY LRHDG I FVL RLVGKNANDV TMIFRQHRIRY LKKFLR INDCYKSEIDKKMAVKFAEQY LRQDGI FVL RLVGKNANDV 
Limax Innexin 10

Lymnaea Innexin 5

Biomphalaria Innexin unc-9-like

Aplysia pannexin 6 Elysia EGW08_005520 partial Pomacea Innexin unc-9-like
1 MAKVISLILTKFLDSAVRTHVRDDDFIDQ

1 MAPIIAS-LTNFANIALRSRVRDDDVIDOLNHWATVGLLFALAMGAGAKOYVGDPI HCWVPAQYTKKHFQ 1 MAPIIASLLSSFANIALRNKAHDDDVVDOLNHWATTGLLFALALGIGAKOYVGDPI HCWVPAEYSKKHFQ 1 MAPVIASILTNFANIALRSRIRDDDA IDOLNHWASSGLLLALAIGTGAKOYVGDPIHCWVPALYKKKHFQ 1

1 MAKLLGSLLLQFSDIG-GQRIHDDDAVD

\section{* TM2}

71 KYSDSYCWIYPMYSFSFDEPI PAKASDRWFNDISYYRWVF IMFLLQAFMFKFPNLIWKHLKNYCGLNVAK 70 QYSDSYCWVFPMYNIPFDEPIPFAPDDRWYNDIGYYRWVF IVF LLQAFLFKFPHMV

71

71 QYCDSYCWVHPMYNVPFEETIPKAEEDRWYNDISY KYSDSYCWI HPMYNVPMEDSI PFDEEERWFNDVGEYRWVEL KYSDSYCW I HPMYNVPMDEE I PFHAKDRWFNDVGEYRWVFLMFLLQAFFFKFPN II

GYADSYCWINSMYYIPFNEAIPFSEEDRWEFDFNE

141 LIGMAWDTNMLTQDKRDEKMEHMAVF IDKWLTTY

140

\section{TM3}

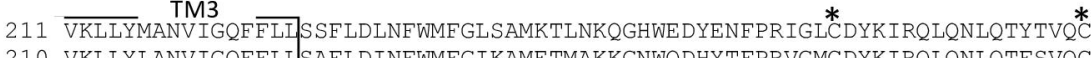

211 TKILYFVNVIGQFFLISAFLDINFWTFGFRAIESLFKKGNWQDHHTFPRVGWCDYKVRQLQNLQTYTLQC 211 TKLLYFVNVIGQFFLI SAF LDLNFWRFGIDAFT IWNKKGRWQDLYNFPR IGLCDYKVRQLENIQTLSVQC

TM4

281 VLS INLFLEKMY LILWFWLILMVAFDSVNLLQWI IRGLRPHSGESF LVKYLHLMDVDTKEEKKDFVRFVH 280 VLS INLFLEKMY I FWFWLVMLLVFNSVNLLHWLLRALVPHTGENF LSKYLTLLNINTKNETKIFKREVS 281 VLS INLFLEKMY L IFWCWL IMLLVFNAVNLFQW IMRS ILPRTGEDFFSKYFLLLNINKNKE SKLFKKFVR 281 VLS INLFLEKMY LILWFWLVMLLVFNTVNMIQW I IRG ISQTRSEAF LAKNLNLLGIDSKRQRKLFVRFTR 237 VLSINMELEKMYLIVWFWLVELLIADMINFGQWLFRALFPRAGERF LGKYLLLLGIDRKREKALFKKFVN 280 VLSVNLELEKI 世LLIF

351 SYLRSDGVFMLRMVAENTSEIMVLDLIKHLWKKFKELHCLKDAD------ADQVVENGA

350 NYLRTDGVFMMRIVAGN IGDMLTLDLVSOLWKMYKOHHGLKDSEDV----NONLGPNGK-----PAS--P 351 NYLRTDGVFMMRIVASN IGDMLALDLVNHLWKKFKDTHSLKEDDDI----GTNERTNGL-----PKS--P 351 NYLRTDGVFMLRIVADNTSEIMTLDLLKQLWKKEKESH--HEDE------GDLHKPNGD-----PVAD-P 307 KHLHADGIFMLRIVAGNTSEILTLDLVRHLWDRFKAVHGLAPSEGATGAPSPDKGPKGSGGEKPPLAROP 350 NYLRNDGVFIIRMLAKNCGHIPSLDLVKQLWITFS-----KDLERR----DRRHAQNG GT -----PRML-P

410 SAPSIDDEDEDFEPIEPKKIL

409 TAPEVEDNDDD---LPPKKED

410 SAPVIEDGDDD---LPLKRLD

407 SAPLVEDNDDS---IPPKNVD

377 SAPIVEEDDDN---LPPKMID

405 SAPGELEM---------- 
Limax Innexin $11 \times 1$

Limax Innexin $11 \times 2$

Limax Innexin 12 partial

Lymnaea FX187001

Elysia EGW08_022284 partial Biomphalaria Tnnexin-19-likex1 Aplysia innexin unc-9-likex2

\section{1}

1

1

1

1 1

38

38

0

38

38

71

38

108

108

1

108

108

140

107

177

177

64

178

210

177

247

247

118

248

247

246

247

317

317

118

318

317

246

317

387

387

118

388

387

246

387

450

450

118

452

456

246

457

TM2

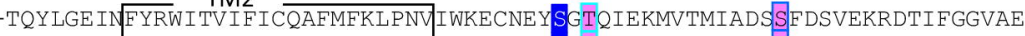
-TQYLGE IN FYRWITVIFICQAFMFKLPNVIWKECNEYS $------I N Y Y R W I G V I F I C Q A I M F K L P N M V W T A C N E Y$ VTKELGEINFYRWITVIFLVQALMFKLPNVVWNECNEY -SNTVGEIN FYRWITVVFIAQALMFKLPNIIWQGANEYSG QEKMVTMIADS TQIEKIVSIVGNSS FDSVERRTIFGGVAE NSETVGQ IN FYRW ITV I FLVQALLFKL PNI VWN I CNEYS

QIEKMVTMISDSS ETSENKQVLFESVAR DSTDKKNNIFASVAE NNEDLGE INEYRWITIVEIFOAFLFKLPNLVWTECNEYSG

IEKMVTMIADSS FSKEKKATTFSSVAE

TM3 EGKDRKA SVESSVAE

FLEIWLKINRKPFWFMKSRVGRQTKKI LQHWMLCMGANTGNYMSTMYLAVKAFFLVNVILQFVI工TAFLD FLE IWLKINRKPFWEMKSRVGRQTKK I LQHWMLCMGANTGNYMSTMYLAVKAFFLVNVILQFVILTAFLD YLE IWMKINRKPHCFMKSQ I DQKAQK I LQNWMFCVGANMGNSLSTMYLVVKAMFL

FLETWLKINRKPFWEMKSRVGAQSKKILRYWMLCMGANTGNYLSTMYLVVKALFLFNVILQF IMLTAFLD YIETWLKINRKPFWEMKSRIGRQTKK I LEHCMLCVGANTGNYLSSMYLVVKALFLINVFLQFAILTAFLE YLETWLKINRKPEWEMKNRVTQQSKKVRHLLYNRESF-- FMERWLVINRKPFWEMKSRVGMQTKKILQHCMLCVGANTGNYL

$*$

FNYWHYGPRALQIYYDTQEKMDN I HF PRVALCHFQARGYGAWVQCLLT INMLLEKMF ENYWHYGPRALQ IYYDTQEKMDN I HF PRVALCHFQARGYGAWVQCLLT INMLLEKMF

FNYWHYGARALEIYHQSRSTQDRTHF PRVALCHFQARGQGSWIQCLLT INMLLEKLF ENFWPYGPQALEIYSETETTVDHVHF PRVALCHFQVKGTGSWIQCLLT INMLLEKIF I

ENYWEYGPKAVQYYQDSGTKIDSGHFPRVAI

Hitor

FQVRGEGQWIQCLLTINMLLEKLF

TIYSFITWLTRILRTDQSVKFVTKYLSVLNEDGSLPQEGKRTVVTFVRDYLGNDGVF LLRILATNTNDVV TIYSFITWITRILRTDQSVKFVTKYLSVLNEDGSLPQEGKRTVVTFVRDYLGNDGVF LLRILATNTNDVV TTYSLFKWV TRI

TSFSMISWI

-

TLYSFVTWL

RILRTQ

TM4

MSELISSVWKRYIDYKNTAVKP-EPPKEPEPSINLTLDELEMDPLSVPADTLDKIYGFNDEHHIA----MSELISSVWKRYIDYKNTAVKP-EPPKEPEPSINLTLDELEMDPLSVPADTLDKIYGFNDEHHIA-----

$\mathrm{MS}$

SELICSVWKRY IDYNNVAIKP-EPVKEPEPSI DMTLDEIEMDPLVSEKEALHLNDTNDTNDLHIA--MAGMVCSLWLRYVSYENKVVEH-PYKVTSEPSNDLELEVLKPAETEGSDPRDAGAGDGADVDKGKNPGKD MSE

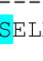

$------$

$-----$

$-----$

DPGISFS

HHTA---
246 246 246 